\title{
RAZGLEDI
}

\section{SEDEMDESET LET RAZISKOVANJ NA GEOGRAFSKEM INŠTITUTU ANTONA MELIKA ZRC SAZU}

\author{
AVTORJA
}

\section{dr. Drago Perko}

Znanstvenoraziskovalni center Slovenske akademije znanosti in umetnosti, Geografski inštitut Antona Melika, Gosposka ulica 13, SI - 1000 Ljubljana, Slovenija; drago@zrc-sazu.si

\section{dr. Matija Zorn}

Znanstvenoraziskovalni center Slovenske akademije znanosti in umetnosti, Geografski inštitut Antona Melika, Gosposka ulica 13, SI - 1000 Ljubljana, Slovenija; matija.zorn@zrc-sazu.si

DOI: $10.3986 / G V 88207$

UDK: 910.1:001.32(497.4)(091)

COBISS: 1.02

\section{IZVLEČEK}

\section{Sedemdeset let raziskovanj na Geografskem inštitutu Antona Melika ZRC SAZU}

Geografski inštitut je leta 1946 ustanovila Slovenska akademija znanosti in umetnosti in ga leta 1976 poimenovala po največjem slovenskem geografu, akademiku Antonu Meliku (1890-1966). Od leta 1981 je sestavni del Znanstvenoraziskovalnega centra Slovenske akademije znanosti in umetnosti (ZRC SAZU). Zdaj je s 33 raziskovalci največja slovenska geografska ustanova. Izdaja šest periodičnih znanstvenih publikacij: revijo Acta geographica Slovenica in pet knjižnih zbirk. Njegovi raziskovalci se ukvarjajo predvsem s temeljnimi in $z$ uporabnimi geografskimi raziskavami Slovenije in njenih pokrajin. Pripravljajo temeljne geografske knjige o Sloveniji, sodelujejo pri številnih domačih in mednarodnih projektih, organizirajo znanstvena srečanja, izmenjujejo znanstvene obiske, izobražujejo mlade raziskovalce, poučujejo na fakultetah.

\section{KLJUČNE BESEDE}

geografija, zgodovina, raziskovanje, Geografskem inštitutu Antona Melika, Slovenija

\begin{abstract}
Seventy years of research at the ZRC SAZU Anton Melik Geographical Institute

The Geographical Institute was founded in 1946 by the Slovenian Academy of Sciences and Arts. In 1976 it was named after Slovenia's greatest geographer, academy member Anton Melik (1890-1966). Since 1981, the Institute has been one of the members of the Research Centre of the Slovenian Academy of Sciences and Arts (ZRC SAZU). With 33 researchers the Institute is now the largest Slovenian geographical institution. The institute issues six scientific periodical publications: the Acta geographica Slovenica journal and five book series. The Institute researchers are engaged in basic and applied geographic research on Slovenia and its landscapes. They prepare basic geographical books on Slovenia, participate in numerous national and international projects, organize scientific conferences, participate in professional exchanges, train junior researchers, and teach at universities.
\end{abstract}

\section{KEY WORDS}

geography, history, research, Anton Melik Geographical Institute, Slovenia

Uredništvo je prispevek prejelo 10. oktobra 2016. 


\section{Uvod}

Geografski inštitut je leta 1946 ustanovila Slovenska akademija znanosti in umetnosti (SAZU) in ga leta 1976 poimenovala po akademiku dr. Antonu Meliku (1890-1966). Od leta 1981 je sestavni del Znanstvenoraziskovalnega centra Slovenske akademije znanosti in umetnosti (ZRC SAZU). Leta 2002 sta se inštitutu priključila Inštitut za geografijo, ki je bil ustanovljen leta 1962, in Zemljepisni muzej Slovenije, ustanovljen leta 1946. Ima sedem oddelkov ter zemljepisno knjižnico in zemljepisni muzej. V njem je sedež Komisije za standardizacijo zemljepisnih imen Vlade Republike Slovenije.

Inštitut izdaja šest periodičnih znanstvenih publikacij: revijo in pet knjižnih zbirk. Njegovi raziskovalci se ukvarjajo predvsem z geografskimi raziskavami Slovenije in njenih pokrajin ter pripravo temeljnih geografskih knjig o Sloveniji. Sodelujejo pri številnih domačih in mednarodnih projektih, organizirajo znanstvena srečanja, izmenjujejo znanstvene obiske, izobražujejo mlade raziskovalce, poučujejo na fakultetah.

Geografski inštitut Anton Melika Znanstvenoraziskovalnega centra Slovenske akademije znanosti in umetnosti (GIAM ZRC SAZU) se je iz skromnih začetkov leta 1946 razvil v največjo slovensko geografsko ustanovo. Njegov razvoj na zgoščen način najbolj sistematično prikazujejo letna poročila o delu inštituta, ki jih je med letoma 1948 in 1996 objavljala Slovenska akademija znanosti in umetnosti v svojem Letopisu (Letopisi ...), od leta 1997 pa jih izdaja Znanstvenoraziskovalni center Slovenske akademije znanosti in umetnosti v svoji publikaciji Poročilo o delu (Poročilo...).

\section{Kratka zgodovina}

Za ustanovitev geografskega inštituta je poskrbel največji slovenski geograf Anton Melik, ki je v prvem Geografskem vestniku po drugi svetovni vojni zapisal: »... Prej ali slej se bo tudi pri nas učinkovito uveljavilo načrtno gospodarjenje in geografija bo imela hvaležno nalogo, da pri tem sama aktivno sodeluje s proučevanji, z nasveti in z dejansko pomočjo svojih spoznanj. Geografija je aktualna veda, če smemo uporabiti ta nemara nekoliko banalni izraz; ko proučuje relief, prirodne osnove za gospodarsko izrabo, klimatske pogoje in sploh možnosti, ki jih je narava nudila človeku za gospodarjenje, mora nujno s temi pogoji primerjati dejansko stanje gospodarske izrabe, obstoječo gospodarsko in naselbinskogeografsko stanje, stem pa se že postavlja kritika in se ustvarja osnova za načrtno gospodarsko preurejanje. Geografiji je po notranjih funkcijskih pogojih stroke odmerjen celo prav znaten delež pri tem. Prevzemamo ga s svežo podjetnostjo, z vročo željo po uveljavljanju doseženih izkušenj in spoznanj, pa po novih preučevanjih, novih prizadevanjih ... (Melik 1945, 113). Geografija se je z novimi raziskovalnimi zamislimi na preseku nacionalnih in prostorskih oziroma humanističnih, naravoslovnih in družboslovnih znanosti dejavno vključila v takratno povojno obnovo in razvoj načrtnega gospodarstva (Ilešič 1946; 1950, 218), kar je olajšala ustrezna organiziranost geografskih raziskav in raziskovalcev v obliki inštituta.

Ustanovitev in razvoj geografskega inštituta sta tesno povezana s Slovensko akademijo znanosti in umetnosti. V Začasni uredbi o Akademiji znanosti in umetnosti v Ljubljani, ki sta jo 6. septembra 1945 podpisala predsednik Narodne vlade Slovenije Boris Kidrič in minister za prosveto dr. Ferdo Kozak, je bila opredeljena temeljna naloga Akademije znanosti in umetnosti »..., da goji znanost in podpira razvoj umetnosti, da povzroča in podpira raziskovanja na tem torišču, objavlja znanstvena dela ter pomaga skrbeti za znanstveni naraščaj ... " (Letopis SAZU 2, 11). Akademija je te naloge prenesla na svoje inštitute in že v prvem letu delovanja geografskega inštituta izdala Melikovo monografijo Ljubljansko mostiščarsko jezero in dediščina po njem (Melik 1946; Letopis SAZU 2, 148). V poročilu z Glavne skupščine 21. decembra 1946 pa je zapisano tudi: »... Akademija znanosti in umetnosti je podprla ... raziskovanje Triglavskega ledenika... « (Letopis SAZU 2, 146), kar inštitut še vedno izvaja, tako da je preučevanje Triglavskega ledenika sploh najstarejši stalni znanstveni projekt v Sloveniji. 
Skupščina Slovenske akademije znanosti in umetnosti je 6. novembra 1948 sprejela statut geografskega inštituta (Arhiv predsedstva SAZU iz leta 1948). V drugem členu statuta inštituta so navedene glavne naloge in dejavnosti: „Geografski institut ima nalogo, da vodi in organizira znanstveno delo na vseh področjih geografske stroke. Svoj namen dosega po naslednjih poteh: a) goji splošna teoretska poglavja geografske znanosti, $b$ ) vodi in organizira znanstveno geografsko proučevanje našega področja, $c$ ) skrbi za objavljanje rezultatov znanstvenih proučevanj, č) eno bistvenih svojih nalog vidi v tem, da pospešuje pri znanstvenem proučevanju one smeri, ki imajo praktične učinke in da stem pripomore k gradnji našega novega življenja, d) da sodeluje z vsemi ustanovami v okviru Akademije in izven nje v pospeševanju navedenih smotrov."

Tretji člen pravi: „Geografski institut organizira proučevalne odprave, prireja znanstvene sestanke in predavanja ter more izdajati svoj strokovni časopis. ", četrti člen pa: »Naloge Geografskega instituta se morejo s sklepom večine njegovih članov in s pristankom razreda in prezidija Akademije razširiti ali spremeniti.«

V petem členu je navedena možna delitev inštituta: "Geografski institut pri Akademiji znanosti se more deliti na tri sekcije: a) na sekcijo za fizično geografijo, b) na sekcijo za geografijo človeka, c) na sekcijo za regionalno geografijo.", šesti člen pa pravi: "Delo Geografskega instituta se more razdeliti v pododseke in komisije, tudi v začasne, ki trajajo toliko časa, da se izvrši postavljena naloga. " (Letopis SAZU 3, 39; Arhiv predsedstva SAZU iz leta 1948). Čeprav takratni statut ne velja več, pa so glavne naloge inštitute še danes skoraj iste.

Pomemben datum je 25. marec 1976, ko je Skupščina Slovenske akademije znanosti in umetnosti ob desetletnici Melikove smrti inštitut poimenovala po njem (Ilešič 1976, 3).

Do prve večje statusne spremembe inštituta je prišlo 19. novembra 1981, ko je SAZU ustanovila ZRC SAZU in so vsi inštituti iz okrilja SAZU prešli na novo znanstveno ustanovo, do druge pa 30. julija 2002, ko je Vlada Republike Slovenije inštitutu priključila prej samostojni Inštitut za geografijo. Danes na javnem zavodu ZRC SAZU deluje 18 inštitutov, geografski inštitut pa je drugi največji.

\section{Predstojniki inštituta}

Vodje inštituta so se sprva imenovali upravniki, od leta 1995 pa predstojniki (slika 1).

Inštitut je od ustanovitve do 8.6.1966 vodil akademik dr. Anton Melik, nato do 28.2.1967 geolog akademik dr. Ivan Rakovec, do 30. 6. 1981 akademik dr. Svetozar Ilešič, do 10.4.1983 akademik dr. Ivan Gams, do 30.5.1987 dr. Milan Šifrer, do 31.12.1991 dr. Drago Meze, do 7.7.1994 Milan Natek, od 8.7.1994 pa inštitut vodi dr. Drago Perko (Natek in Perko 1999, 17-20).

\section{Organizacijske enote inštituta}

Danes ima inštitut 9 enot: knjižnico, muzej ter oddelke za fizično, humano in regionalno geografijo, naravne nesreče, varstvo okolja, geografski informacijski sistem in tematsko kartografijo.

Najstarejša enota je Zemljepisni muzej, ki je bil ustanovljen 7.5. 1946 kot Zemljepisni muzej Slovenije (Zorn in Gašperič 2016), kar velja za uradni rojstni dan inštituta. Oddelek za tematsko kartografijo je bil ustanovljen 7. 2. 1952 kot Kartografski zavod (Arhiv predsedstva SAZU iz leta 1952; Letopis SAZU 5, 183), Oddelek za naravne nesreče 1.1.1992 kot Center za multidisciplinarno preučevanje naravnih nesreč (Letopis SAZU 43, 279), Oddelek za fizično geografijo (sprva geoekologijo), Oddelek za regionalno geografijo in Oddelek za geografski informacijski sistem 14. 10.1994 (Natek in Perko 1999, 27-28), Oddelek za humano geografijo (sprva družbeno geografijo) in Oddelek za varstvo okolja pa 1.9.2002. 


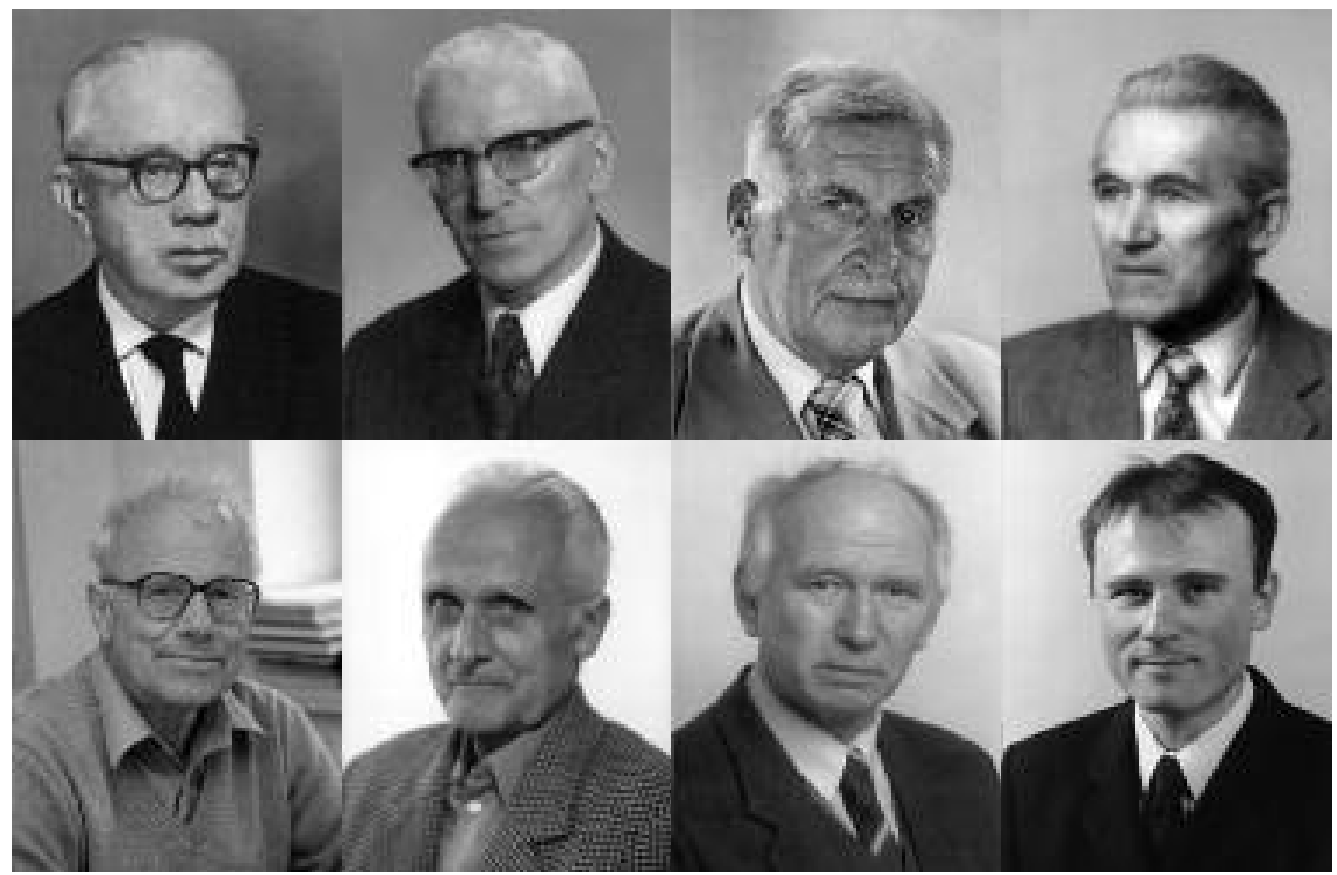

Slika 1: Predstojniki inštituta od leta 1946: Anton Melik, Ivan Rakovec, Svetozar Ilešič, Ivan Gams, Milan Šifrer, Drago Meze, Milan Natek, Drago Perko.

\section{Publikacije inštituta}

Raziskovalci inštituta objavljajo pri domačih in tujih založbah, največ pa v izdajah inštituta. Trenutno inštitut izdaja pet znanstvenih knjižnih zbirk in znanstveno revijo.

Najdaljšo tradicijo ima revija Acta geographica Slovenica (ISSN tiskane različice: 1581-6613, ISSN digitalne različice: 1581-8314; slika 2). Ustanovljena je bila leta 1952 z imenom Geografski zbornik/Acta geographica (ISSN 0373-4498). Skupaj je izšlo 42 številk (Natek in Perko 1999, 38-41). Leta 2002 se ji je priključila znanstvena revija Geographica Slovenica (ISSN 0351-1731, ustanovljena leta 1971, 35 številk). Od leta 2003 (z letnikom 43) je naziv skupne revije Acta geographica Slovenica, številčenje letnikov pa sledi starejšemu Geografskemu zborniku (Zorn in Komac 2010; Urbanc, Kladnik in Perko 2014). Sedanja Acta geographica Slovenica izhaja dvakrat letno v angleškem in slovenskem jeziku. Od leta 1995 revija izhaja tudi na medmrežju, od leta 2016 so v digitalni obliki na voljo tudi vse starejše številke Geografskega zbornika in Geographice Slovenice.

Najstarejša publikacija inštituta je zbirka Dela Inštituta za geografijo (slika 3), ki jo je zalagala Slovenska akademija znanosti in umetnosti, saj je do leta 1981 inštitut deloval še v njenem okviru. V petdesetih letih 20. stoletja je izšlo pet knjig, v šestdesetih letih pa šest. Vseh enajst monografij skupaj presega 2300 strani (Natek in Perko 1999, 41).

Tradicijo zbirke Dela Inštituta za geografijo nadaljuje zbirka Geografija Slovenije (slika 4), ki je namenjena objavam obsežnejših, vsebinsko zaokroženih monografij s področja fizične, humane in regionalne geografije Slovenije ter slovenske geografske terminologije, slovenskih zemljepisnih imen in slovenske tematske kartografije. Objavljena dela obravnavajo določen problem celovito, na območju celotne Slovenije, določen problem na ožjem področju, a je ta problem značilen za Slovenijo, ali določen 


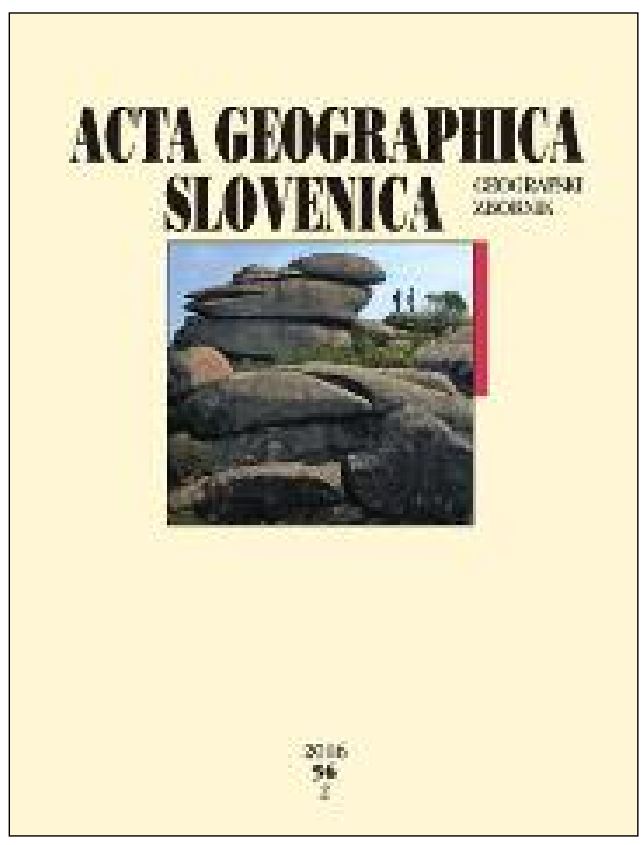

Slika 2: Naslovnica revije Acta geographica Slovenica.

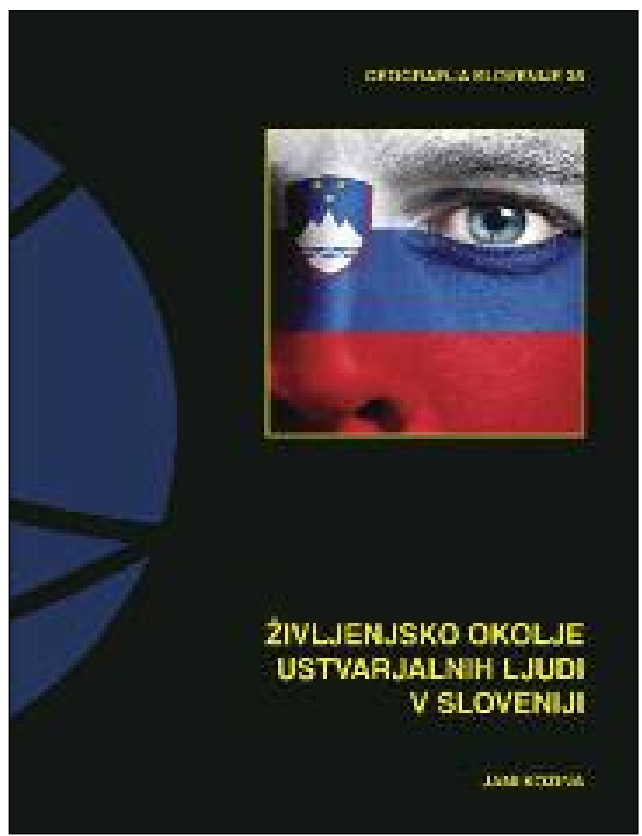

Slika 4: Naslovnica knjižne zbirke Geografija Slovenije.

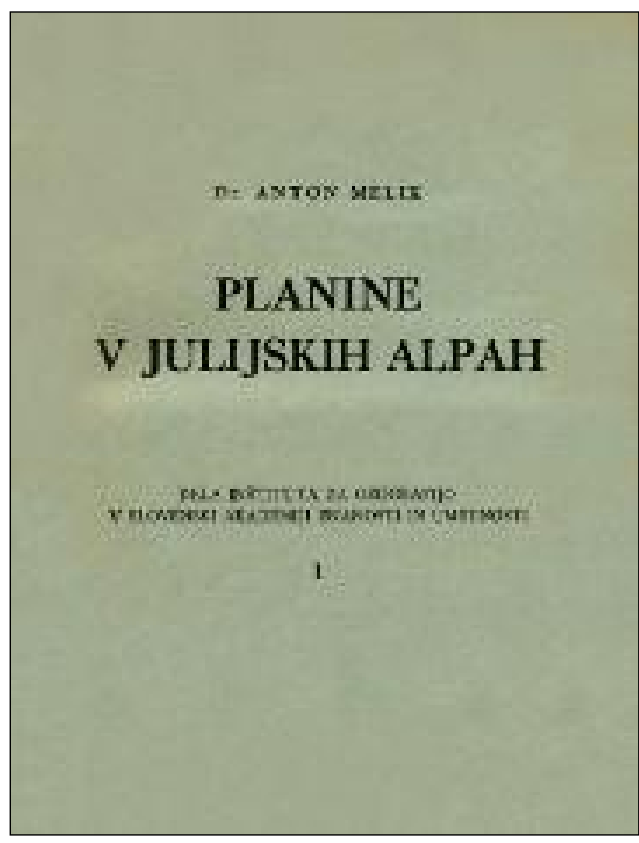

Slika 3: Naslovnica knjižne zbirke Dela Inštituta za geografijo.

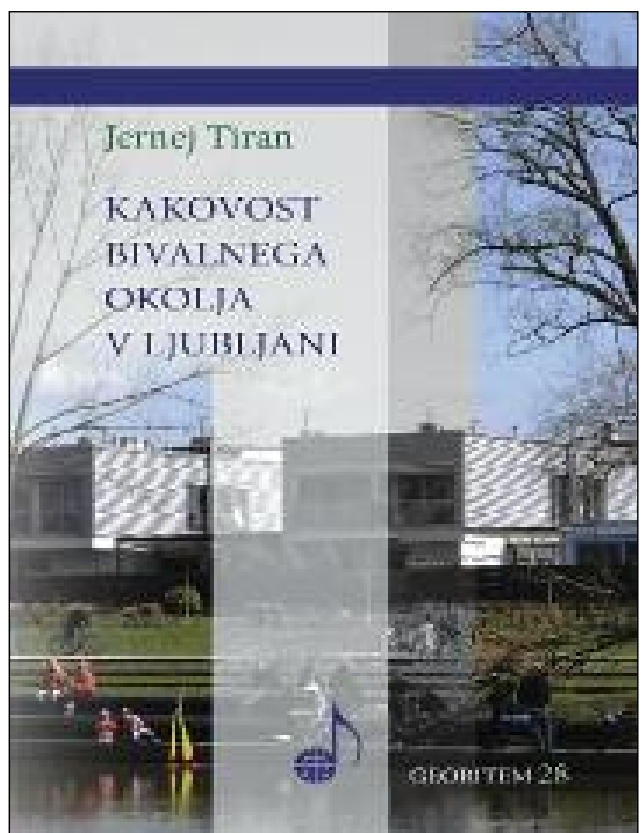

Slika 5: Naslovnica knjižne zbirke Georitem. 
Drago Perko, Matija Zorn Sedemdeset let raziskovanj na Geografskem inštitutu Antona Melika ZRC ...

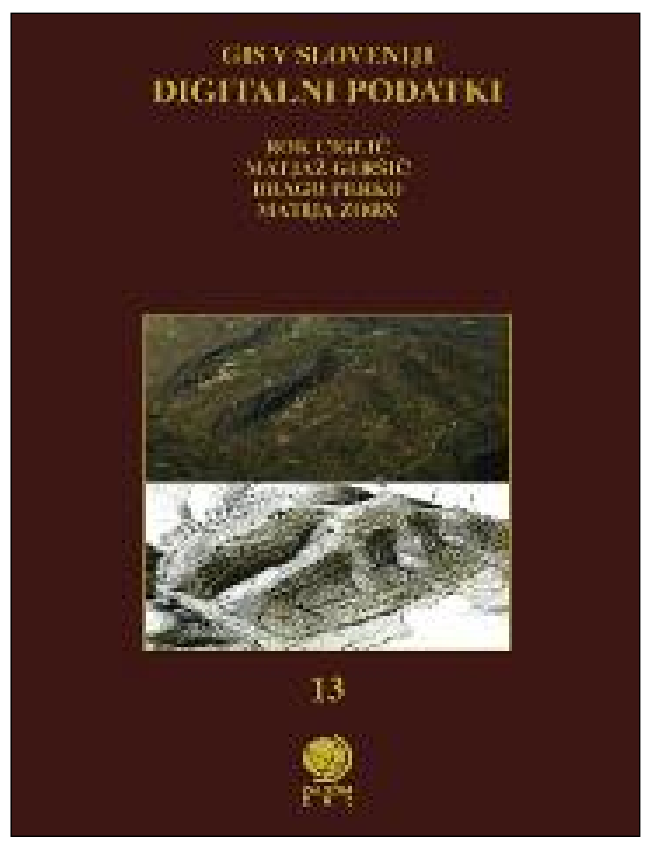

Slika 6: Naslovnica knjižne zbirke GIS v Sloveniji.

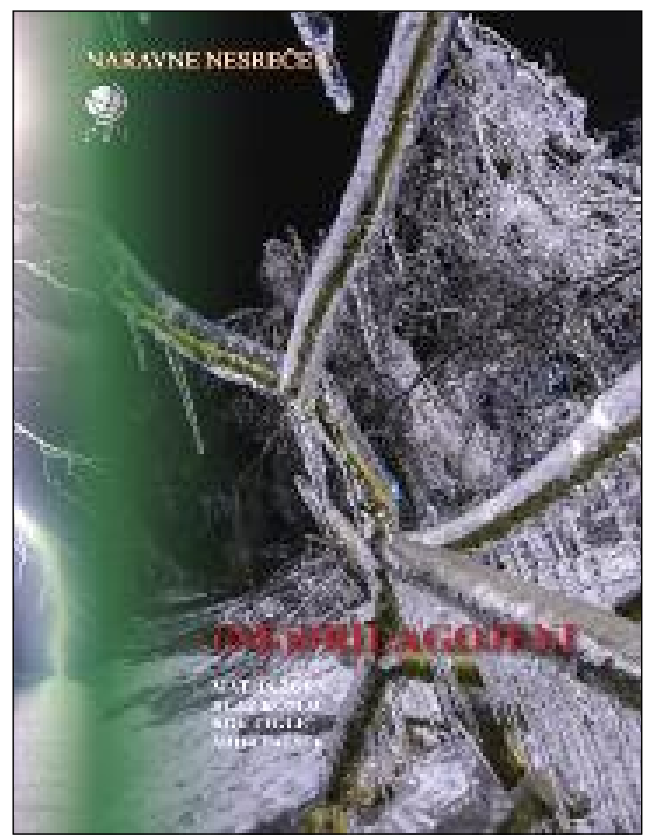

Slika 8: Naslovnica knjižne zbirke Naravne nesreče.

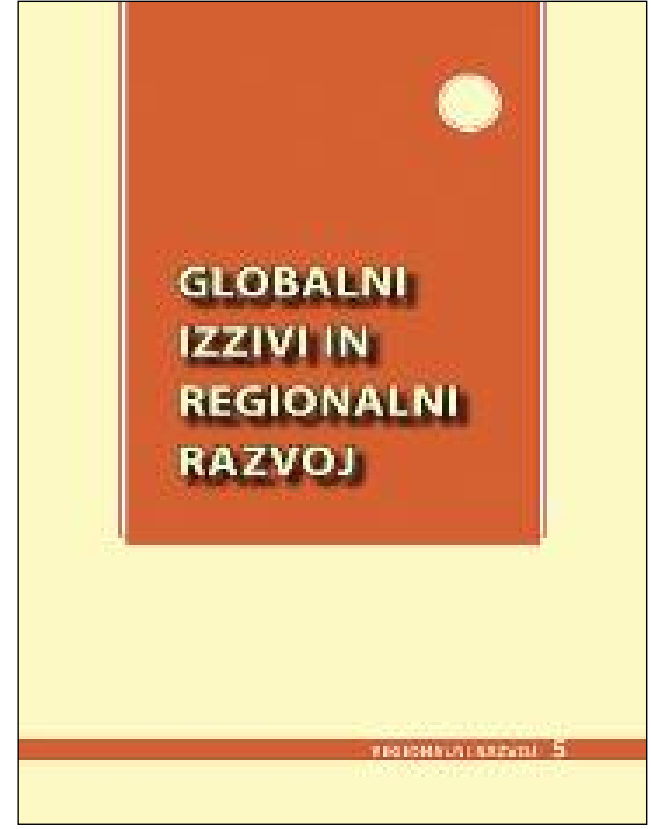

Slika 7: Naslovnica knjižne zbirke Regionalni razvoj.

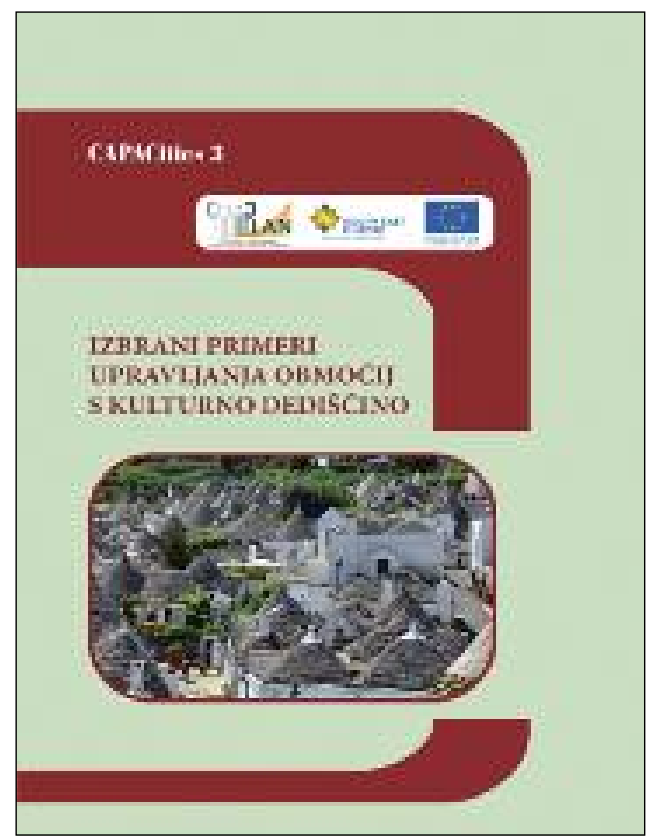

Slika 9: Naslovnica knjižne zbirke CAPACities. 
problem primerjalno med Slovenijo in tujino. Zbirka izhaja od leta 1999, do konca leta 2016 pa je izšlo 35 monografij.

V zbirki Georitem (slika 5) izhajajo predvsem celovite predstavitve vsebinsko ožjih problemov s področja geografije in sorodnih ved, večinoma so to rezultati inštitutskih domačih in mednarodnih projektov. Zbirka izhaja od leta 2007, do konca leta 2016 pa je izšlo 28 monografij.

Zbirka GIS v Sloveniji (slika 6; Perko in Zorn 2010) je multidisciplinarna bienalna monografska publikacija, ki izhaja v sodih letih in prinaša presek dveletnega znanstvenega, strokovnega in pedagoškega dela na področju razvoja ter uporabe geografskih informacijskih sistemov v Sloveniji. Prva knjiga je izšla leta 1992, leta 2016 pa že 13. monografija.

Tudi zbirka Regionalni razvoj (slika 7) je multidisciplinarna monografska publikacija. Izhaja v lihih letih. Sega na področja regionalne politike, regionalnega razvoja, regionalizacije ter splošnih razvojnih vprašanj. Vsaka posamezna knjiga je posvečena izbrani tematiki, pri čemer skuša pritegniti različne avtorje, ki lahko prispevajo k celoviti in kakovostni obravnavi le-te. Prva knjiga je izšla leta 2007, šesta pa izide 2017.

Tretja multidisciplinarna zbirka ima naslov Naravne nesreče (slika 8). Posamezne monografije v zbirki celostno predstavljajo delo na znanstvenih, razvojnih, izobraževalnih in drugih področjih v Sloveniji v zadnjem triletnem obdobju. Leta 2017 izide peta monografija.

Med letoma 2010 in 2014 je izhajala tudi zbirka CAPACities (slika 9). Objavila je rezultate istoimenskega mednarodnega projekta, ki se je ukvarjal s problematiko privlačnosti in konkurenčnosti malih alpskih mest. Izšle so tri monografije.

\section{Znanstvenoraziskovalno delo inštituta med letoma 1946 in 2001}

V štiridesetih in petdesetih letih 20. stoletja so na inštitutu prevladovale geomorfološke raziskave, še posebej pleistocenske poledenitve (Šifrer 1952; 1955; 1959; 1961b; 1963; Melik 1954; 1955a; 1955b; 1959; 1961; Gams 1959; 1961a). Poleg rednega letnega merjenja ledenikov pod Triglavom in Skuto so sodelavci inštituta leta 1950 in 1951 evidentirali vsa večja snežišča, »zelene snegove« v slovenskih Alpah (Gams 1961b; Šifrer 1961a). Izšla je prva pregledna študija o obeh slovenskih ledenikih (Meze 1955). Leta 1956 je pozornost vzbudil dotlej prezrti ledenik Skedenj pod Prisankom. Leta 1950 se je začelo sistematično preučevanje planin (Melik 1950; 1956) in naravnih nesreč (Gams 1955; Meze 1959; Šifrer in Žagar 1960; Šifrer 1962), leta 1951 pa raziskovanje zgornje meje gozda, trajnega snega, naseljenosti, uspevanja in gojenja ozimin, koruze in vinske trte (Gams 1960). Istega leta so se začela široko zasnovana preučevanja poplavnega sveta in kvartarnih nanosov. Vzporedno s temi študijami so v vseh obdobjih potekale tudi številne regionalnogeografske raziskave slovenskih pokrajin.

Šestdeseta leta so bila namenjena predvsem preučevanju kvartarnih sedimentov in njihovi izrabi. Obsežne in dolgotrajne terenske raziskave so dale nekaj temeljnih študij slovenske kvartarne geomorfologije (Meze 1963a; 1966; 1974; Šifrer 1967; 1969; 1972; 1974a; 1974b; 1982; Šifrer in Kunaver 1978; Šifrer, Radinja in Meze 1978; Natek 1983a). Leto 1959 je začetek obsežnega in dolgotrajnega raziskovanja hribovskih kmetij (Meze 1960; 1963b; 1965; 1969; 1979; 1980a).

V sedemdesetih letih so prevladovale raziskave poplavnih območij. Za enoten pristop so bila pripravljena metodološka navodila, v katerih piše tudi: »... Poglavitni namen zastavljenega proučevanja pa vendarle ni sistematska regionalno geografska obdelava poplavnih področij, temveč predvsem prikaz tistih geografskih pojavov in njihovih spletov, ki so za nastanek, razvoj in strukturo poplavnih področij odločilni oziroma najznačilnejši. Poplavna področja kaže zato obravnavati kot posebno vrsto pokrajin, $v$ katerih so vodne razmere dominantna poteza ... « (Radinja in ostali 1974, 131). Poplavna območja v predalpskih kotlinah (Radinja in ostali 1976; Meze 1977; Natek 1978) se po pokrajinskih in hidrografskih značilnostih razlikujejo od panonskih (Šifrer 1977; Šifrer, Lovrenčak in Natek 1980), kraških (Meze 1980b; 1982) ali sredozemskih poplavišč (Orožen Adamič 1979). Pri vseh pa je skupno, da je 
človek $\mathrm{z}$ včasih nepremišljenimi posegi ter zanemarjanjem čiščenja in vzdrževanja rečnih korit povečal pogostost in obseg poplav. Posebna pozornost je bila namenjena prikazovanju in vrednotenju naravnih nesreč (Šifrer 1976), posebej potresov v Posočju leta 1976 (Orožen Adamič 1978; 1982; Orožen Adamič in Kunaver 1978).

Tudi za osrednjo temo osemdesetih let, hribovske kmetije (Meze 1981; 1983; 1985; 1986; 1987; 1988; Natek 1983; 1987; 1992b; Orožen Adamič 1987), je bila izdelana posebna metodologija (Meze 1980a). Sklenila so se preučevanja poplavnih območij (Šifrer 1983; Perko 1992a; 1992b; Natek 1992a). Milan Šifrer je leta 1982 pripravil scenarij za film o Triglavskem ledeniku, ki ga je posnela Radiotelevizija Ljubljana (Letopis SAZU 33, 230), leta 1989 pa še scenarij o sledovih pleistocenske poledenitve v Blejsko-Radovljiški kotlini (Letopis SAZU 40, 316).

Inštitut je izdelal vzorčni osnutek geomorfološke karte ozemlja Litijske kotline, ki je bila kasneje tudi tiskana kot prva jugoslovanska geomorfološka karta, izdelana po mednarodni koncepciji (Letopis SAZU 30, 267-268; Letopis SAZU 31, 174; Gams in Natek 1981; Natek 1986). V okviru izdelave jugoslovanske geomorfološke karte v merilu $1: 500.000$ je inštitut prevzel izdelavo za ozemlje Slovenije.

Preučene so bile vse večje naravne nesreče, zlasti neurja (Šifrer 1980; Natek 1983b; Orožen Adamič in Šifrer 1984), poplave (Orožen Adamič 1983), suše (Natek 1984) ter zemeljski plazovi in usadi (Natek 1989; Natek 1990). Sistematično geografsko preučevanje vzrokov in posledic naravnih nesreč je prispevalo k prvemu strokovnemu posvetovanju s tega področja na Slovenskem, ki je bilo 14. oktobra 1983. Velik prispevek $\mathrm{k}$ multidisciplinarnemu raziskovanju naravnih nesreč je bila ustanovitev revije Ujma, ki je po inštitutski vsebinski zasnovi začela izhajati leta 1987.

Leta 1985 je Milan Orožen Adamič v sodelovanju z Republiškim sekretariatom za ljudsko obrambo izdelal scenarij za film o naravnih nesrečah, ki ga je posnela Radiotelevizija Ljubljana (Letopis SAZU 36, 299).

Leta 1982 je prejel inštitut za pomembne dosežke na področju sistematičnega preučevanja naravnih nesreč, ki so prizadele slovenske pokrajine v preteklih obdobjih, zlato plaketo civilne zaščite. Podelila mu jo je Milka Planinc, predsednica zveznega izvršnega sveta SFRJ (Letopis SAZU 33, 228). Enako priznanje je dobil inštitut od Republiškega štaba civilne zaščite ob svetovnem dnevu civilne zaščite 1. marca 1992.

Inštitut je začel graditi geografski informacijski sistem, ki je v devetdesetih letih postal nepogrešljiv vir bogatih informacij pri vsem znanstvenoraziskovalnem delu inštituta (Perko 1991).

Za raziskovalno delo inštituta sta $\mathrm{v}$ devetdesetih letih pomembna predvsem dva dogodka: osamosvojitev Slovenije leta 1991 in začetek projektnega financiranje raziskovalne dejavnosti v Sloveniji leta 1993.

Dolgoročne raziskovalne naloge so zamenjali večinoma enoletni, dveletni ali triletni temeljni, aplikativni in ciljni projekti, ki pa jih je inštitut moral pridobiti na razpisih, kar je neugodno vplivalo na finančno stanje inštituta. Po drugi strani pa je država z osamosvojitvijo pokazala zanimanje za pripravo temeljnih geografskih knjig o Sloveniji in to tudi ustrezno finančno podprla, zato to obdobje dela na inštitutu zaznamuje izid večjega števila pomembnih in obsežnih znanstvenih in strokovnih knjig o Sloveniji.

Leta 1995 sta izšla knjiga Krajevni leksikon Slovenije (Orožen, Perko in Kladnik 1995) in istoimenska zgoščenka, ki je bila prva tovrstna zgoščenka v Sloveniji. Tega leta je bila 14. septembra ustanovljena tudi Komisije za standardizacijo zemljepisnih imen Vlade Republike Slovenije, ki jo inštitut vodi še danes.

Leta 1997 je izšel poljudnoznanstveni film Slovenske pokrajine (Perko in Križnar 1997). Leta 1996 je inštitut za nemško založbo Klett-Perthes pripravil multimedijsko knjigo Kulturatlas Europa - Slowenien (Aimée in ostali 1996), ki je leta 1997 izšla tudi v slovenskem prevodu kot Kulturni atlas Slovenija (Aimée in ostali 1997).

Leta 1998 je bil končan petletni pregled zemljepisnih imen na vseh državnih topografskih kartah v merilu $1: 25.000$. Izšli sta kar dve temeljni geografski deli o Sloveniji: knjiga Slovenija - pokrajine in ljudje (Perko in Orožen Adamič 1998) je bila rezultat temeljnega raziskovalnega projekta Regionalna geografska monografija Slovenije in ponatisnjena še leta 1999 in 2001, Geografski atlas Slovenije (Fridl in ostali 1998) pa triletnega projekta Nacionalni atlas Slovenije. Inštitut je za svojo šestdesetletnico izdal faksimile Atlanta (Fridl in ostali 2005), prvega atlasa sveta v slovenskem jeziku, poleg tega pa je v novem tisočletju izdal še več pomembnih knjig (glej poglavje 8). 
Natančnejše delovanje prvih pet desetletij inštituta je opisano v knjigi 50 let Geografskega inštituta Antona Melika ZRC SAZU (Natek in Perko 1999).

\section{Znanstvenoraziskovalno delo inštituta od leta 2002}

Po pridružitvi Inštituta za geografijo Geografskemu inštitutu Antona Melika ZRC SAZU leta 2002 lahko na inštitutu opazujemo dva prepletajoča procesa: kadrovsko krepitev (slika 10) in krepitev mednarodnih projektov (slika 13). Kadrovsko je inštitut okrepila že sama združitev, saj se je število raziskovalcev povečalo z 12 na 19, čez deset let (2012) pa, predvsem zaradi uspešnosti na mednarodnih razpisih in posledične možnosti zaposlovanja mladih raziskovalcev, na skoraj dvakratnik te številke (34). Z letom 2010 se je rast števila raziskovalcev ustavila pri dobrih trideset. Raslo je tudi število mladih raziskovalcev, ki so se v posameznih letih izobraževali na inštitutu: od pet leta 2002 na celo enajst leta 2012. Med letoma 2002 in 2008 je bilo mladih raziskovalcev na inštitutu v povprečju okrog šest na leto, med letoma 2009 in 2015 pa dobrih devet na leto (slika 10).

Ob združitvi je na inštitutu še vedno potekal raziskovalni program Regionalna geografija Slovenije (P0-0515-0618; 1999-2003), ki ga je vodil Drago Perko. Iz nekdanjega Inštituta za geografijo pa se je na združen inštitut prenesel raziskovalni program Socialna geografija (P0-0501-0506; 1999-2003), ki ga je vodil Marjan Ravbar. Slednjega so v grobem sestavljali trije sklopi: preučevanje naselij, preučevanje regionalnega razvoja ter preučevanje okoljskih problemov (Poročilo ... 2003, 124). Raziskovalne prioritete inštituta so se s tem močno razširile, saj so prešle okvire fizične in regionalne geografije, ki so bolj ali manj prevladovali v prejšnjem obdobju, ter se zasidrale tudi na področjih humane geografije in varstva okolja. S tem je povezana tudi omenjena ustanovitev inštitutskih oddelkov za ti področji (poglavje 4).

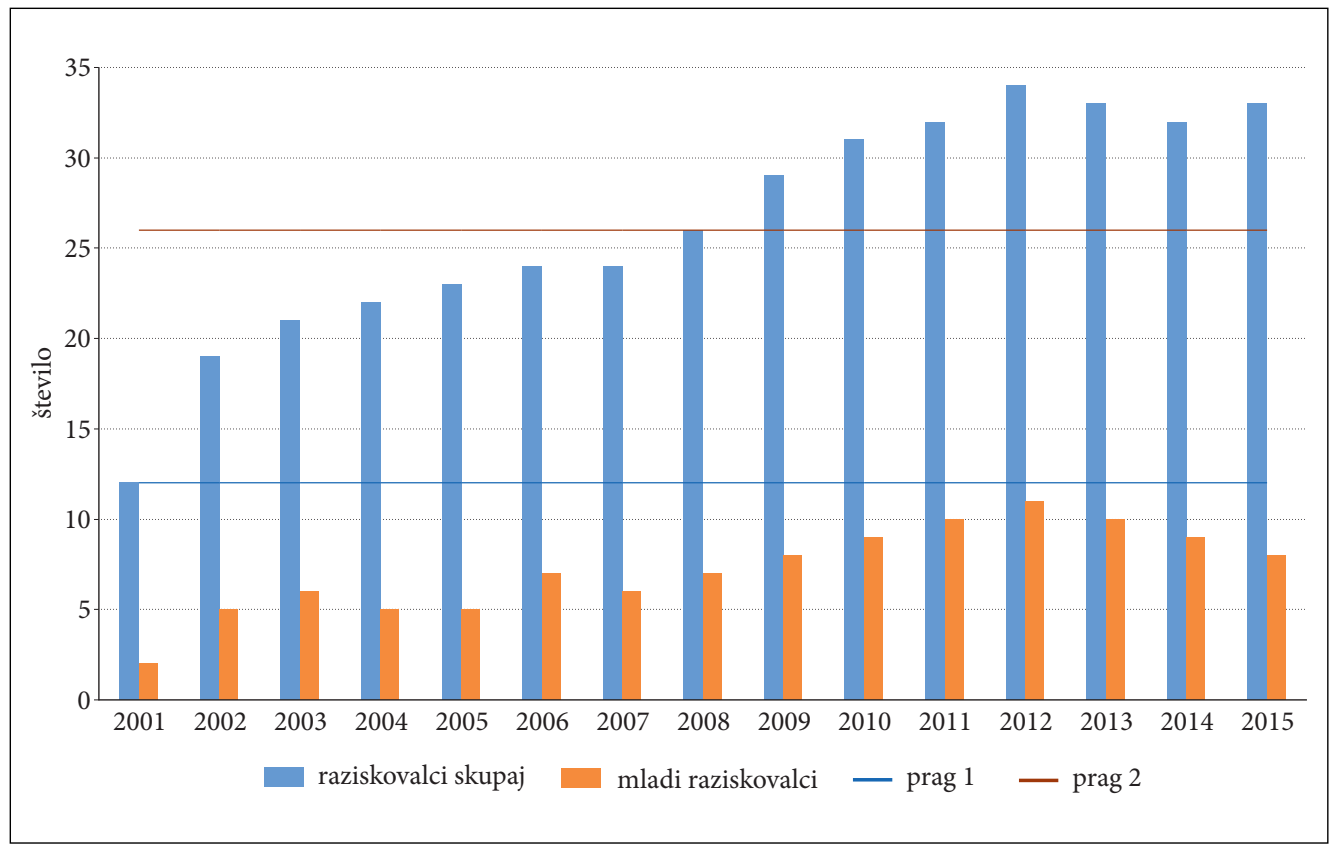

Slika 10: Število raziskovalcev in mladih raziskovalcev med letoma 2001 in 2015 ter pragova, ki kažeta dve sedemletni obdobji kadrovske krepitve inštituta. 
Preglednica 1: Raziskovalni projekti, ki jih je financirala Javna agencija za raziskovalno dejavnost Republike Slovenije in so potekali na inštitutu od leta 2002 ( ${ }^{*}$ nosilec projekta zunaj inštituta; ${ }^{* *} / T$ - temeljni raziskovalni projekt, $L$ - aplikativni raziskovalni projekt, $M / V$ - ciljni raziskovalni projekt, $Z$ - podoktorski raziskovalni projekt).

ime projekta

Geomorfološke oblike in procesi v Sloveniji

Slovenija in nadaljni razvoj Evropske unije*

Integralna obremenjenost prodnih ravnin Slovenije - primer Ljubljanskega polja

Sistem urejanja prostora

Dejavniki skladnega regionalnega razvoja v predvideni pokrajinski ureditvi Slovenije

Razvojne možnosti JPP in poselitve v RS*

(Ne)planirano širjenje urbanih območij - izziv za trajnostni razvoj, urejanje

in načrtovanje prostora ${ }^{\star}$

Spremljanje regionalnega razvoja

Terminološki slovar urejanja prostora I*

Terminološki slovar urejanja prostora II

Metodologija integracije razvojnega in prostorskega načrtovanja ter varstva okolja*

Regionalna primerjava spreminjanja poselitvene rabe zemljišč med statističnimi regijami v Sloveniji v obdobju 1991-2002 po vzorčnih podeželskih območjih

Naselbinski razvoj RS pod vplivi urbanizacije na prelomu tisočletja

Navzkrižja interesov pri rabi podtalnice in možnosti za razreševanje

Skupna zemljišča v Sloveniji: kulturna pokrajina med preteklostjo in prihodnostjo

Triglavski ledenik kot pokazatelj podnebnih sprememb

Za svobodo domovine: Fronta v Julijcih 1915-1917*

Presoja instrumentov in mehanizmov regionalne politike

Učinkovitost in vplivi investicij na regionalni in prostorski razvoj (ekonomsko-geografska analiza investicijskih aktivnosti v obdobju 2004-2006)

Dnevna prometna migracija na delovno mesto in šolo

Trajnostno urejanje prometa na lokalni ravni

Preobrazba pokrajine zaradi posodabljanja kmetijstva in spreminjanja poselitvenega vzorca*

Analiza konfliktov in kulturnih razlik v Severni in Podsaharski Afriki

Izvajanje regionalne politike $\mathrm{v}$ spremenjenih pogojih upravljanja z razvojem zaradi uvedbe novih teritorialnih ravni*

Zapostavljeni spomin pokrajine - Prekmurska zgodovina kot primer spregleda lokalne zgodovine $\mathrm{v}$ učnem načrtu osnovnih in srednjih šol ${ }^{\star}$

Slovenski eksonimi: metodologija, standardizacija, GIS

Geografija človeških virov Slovenije (Geografija ustvarjalnosti)

Določanje naravnih pokrajinskih tipov Slovenije z geografskim informacijskim sistemom

Prometna raba tal: spreminjanje in vpliv na vsakodnevno življenje

Povečanje učinkovitosti in aplikativnosti preučevanja naravnih nesreč s sodobnimi metodami

Šolski učbeniki kot orodje za oblikovanje geografskih predstav o slovenskih pokrajinah

Terasirane pokrajine v Sloveniji kot kulturna vrednota

Prostor slovenske literarne kulture: literarna zgodovina in prostorska analiza z geografskim informacijskim sistemom ${ }^{\star}$

šifra ${ }^{* *} \quad$ trajanje

T6-1042 1999-2003

V6-0628 2001-2003

J6-3286 2001-2004

V6-0607 2002-2003

V6-0628 2002-2004

V2-0692 2002-2004

V5-0723 2002-2004

V5-0488 2002-2004

V5-0843 2003-2005

V6-0977 2004-2006

V5-0960 2004-2005

V5-0903 2004-2006

J6-6360 2004-2007

J6-6116 2004-2007

Z6-7102 2005-2007

L6-7136 2005-2008

M6-0158 2006-2008

V5-0306 2006-2008

V5-0305 2006-2008

V2-0373 2006-2008

V5-0300 2006-2008

V5-0303 2006-2008

M4-0203 2007-2009

V5-0510 2008-2010

V5-0238 2008-2011

L6-0111 2008-2011

J6-2135 2009-2012

L6-3643 2010-2013

Z6-4030 2011-2013

L6-4048 2011-2014

J6-4138 2011-2014

L6-4038 2011-2014

J6-4245 2011-2014 
Generiranje sintetične populacije kot osnova za »activity-based«/»agent-based « mikrosimulacijske prometne modele*

Prostorska utesnjenost kmetij v naseljih

Kulturna pokrajina $\mathrm{v}$ precepu med javnim dobrim, zasebnimi interesi in politikami

Pokrajinska raznolikost in vroče točke Slovenije

Prožnost alpskih pokrajin $\mathrm{z}$ vidika naravnih nesreč

J6-6853

2014-2017

Fenomen mejna reka*

J6-6830

2014-2017

Jezikovna politika Republike Slovenije in potrebe uporabnikov*

V6-1647

2016-2017

Priprava strokovnih izhodišč za turistično in rekreacijsko rabo gozdov*

V4-1630

2016-2018

Model povezovanja prostorskega in razvojnega načrtovanja na regionalni ravni

V6-1652

2016-2018

Umeščanje kmetijskih objektov v krajino in reševanje prostorskih konfliktov

V6-1629

2016-2018

Napredek računsko intenzivnih metod za učinkovito sodobno splošno namensko statistično analizo in sklepanje*

Preglednica 2: Raziskovalni projekti, ki sta jih financirali Javna agencija za raziskovalno dejavnost Republike Slovenije ali Evropska unija in so potekali na inštitutu od leta 2002, po vejah geografije.

\begin{tabular}{lcccc}
\hline & \multicolumn{2}{c}{ domači } & \multicolumn{2}{c}{ tuji } \\
\cline { 2 - 5 } & število & delež (\%) & število & delež (\%) \\
\hline fizična geografija & 4 & 9 & 3 & 17 \\
humana geografija & 22 & 50 & 13 & 72 \\
regionalna geografija & 18 & 41 & 2 & 11 \\
skupaj & 44 & 100 & 18 & 100 \\
\hline
\end{tabular}

Preglednica 3: Raziskovalni projekti, ki sta jih financirali Javna agencija za raziskovalno dejavnost Republike Slovenije ali Evropska unija in so potekali na inštitutu od leta 2002, po ožjih geografskih področjih.

\begin{tabular}{lcccc}
\hline & \multicolumn{2}{c}{ domači } & \multicolumn{2}{c}{ tuji } \\
\cline { 2 - 5 } & število & delež (\%) & število & delež (\%) \\
\hline geomorfologija & 2 & 4,5 & 0 & 0,0 \\
podnebna geografija & 1 & 2,3 & 1 & 5,6 \\
geografija naravnih nesreč & 2 & 4,5 & 2 & 11,1 \\
okoljska geografija & 2 & 4,5 & 3 & 16,7 \\
regionalni razvoj & 11 & 25,0 & 7 & 38,9 \\
urbana geografija & 2 & 4,5 & 0 & 0,0 \\
geografija podeželja & 6 & 13,6 & 0 & 0,0 \\
geografija turizma & 1 & 2,3 & 3 & 16,7 \\
geografija prometa & 5 & 11,4 & 1 & 5,6 \\
didaktika geografije & 1 & 2,3 & 1 & 5,6 \\
geografija ustvarjalnosti & 1 & 2,3 & 0 & 0,0 \\
terminologija in zemljepisna imena & 3 & 6,8 & 0 & 0,0 \\
zgodovinska geografija & 3 & 6,8 & 0 & 0,0 \\
GIS & 4 & 9,1 & 0 & 0,0 \\
skupaj & 44 & 100,0 & 18 & 100,0 \\
\hline
\end{tabular}


Razširjena usmeritev se ne kaže le v raziskovalnem programu, pač pa tudi pri raziskovalnih projektih (preglednice 1-4; sliki 11-12). Delež domačih projektov na področju humane geografije je tako od leta 2002 polovičen, medtem ko je delež fizičnogeografskih projektov pod $10 \%$. Pri tujih projektih

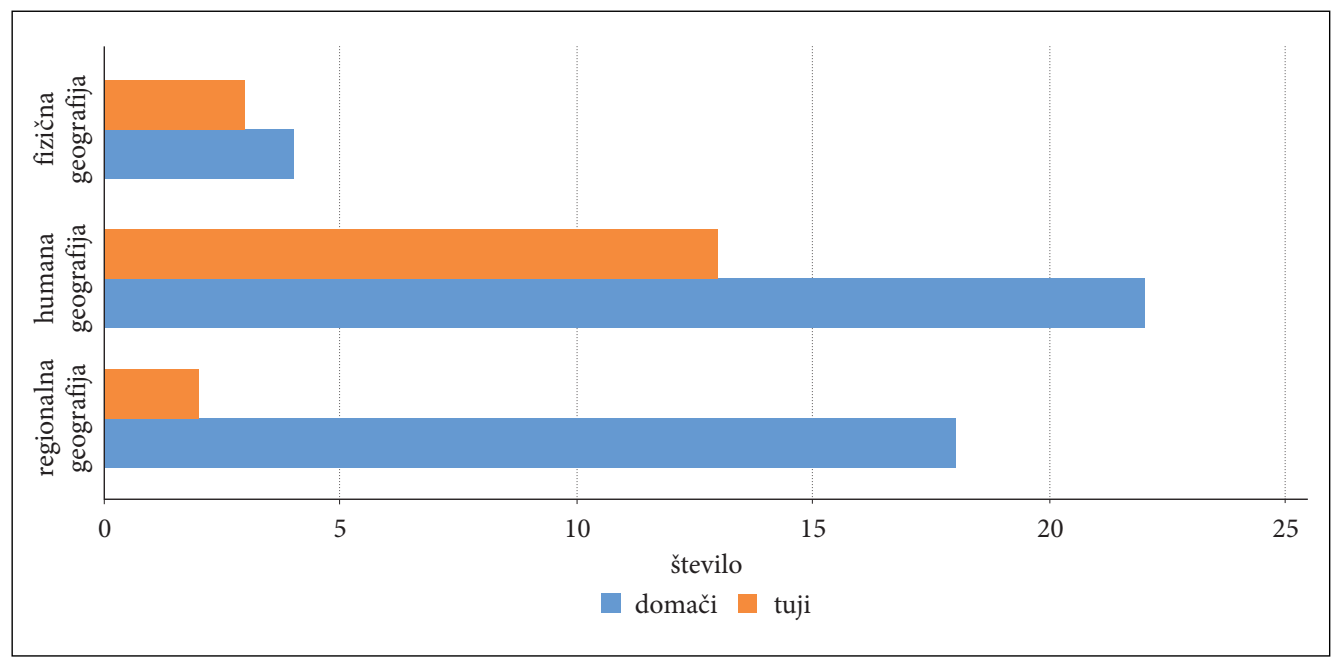

Slika 11: Raziskovalni projekti, ki sta jih financirali Javna agencija za raziskovalno dejavnost Republike Slovenije ali Evropska unija in so potekali na inštitutu od leta 2002, po vejah geografije.

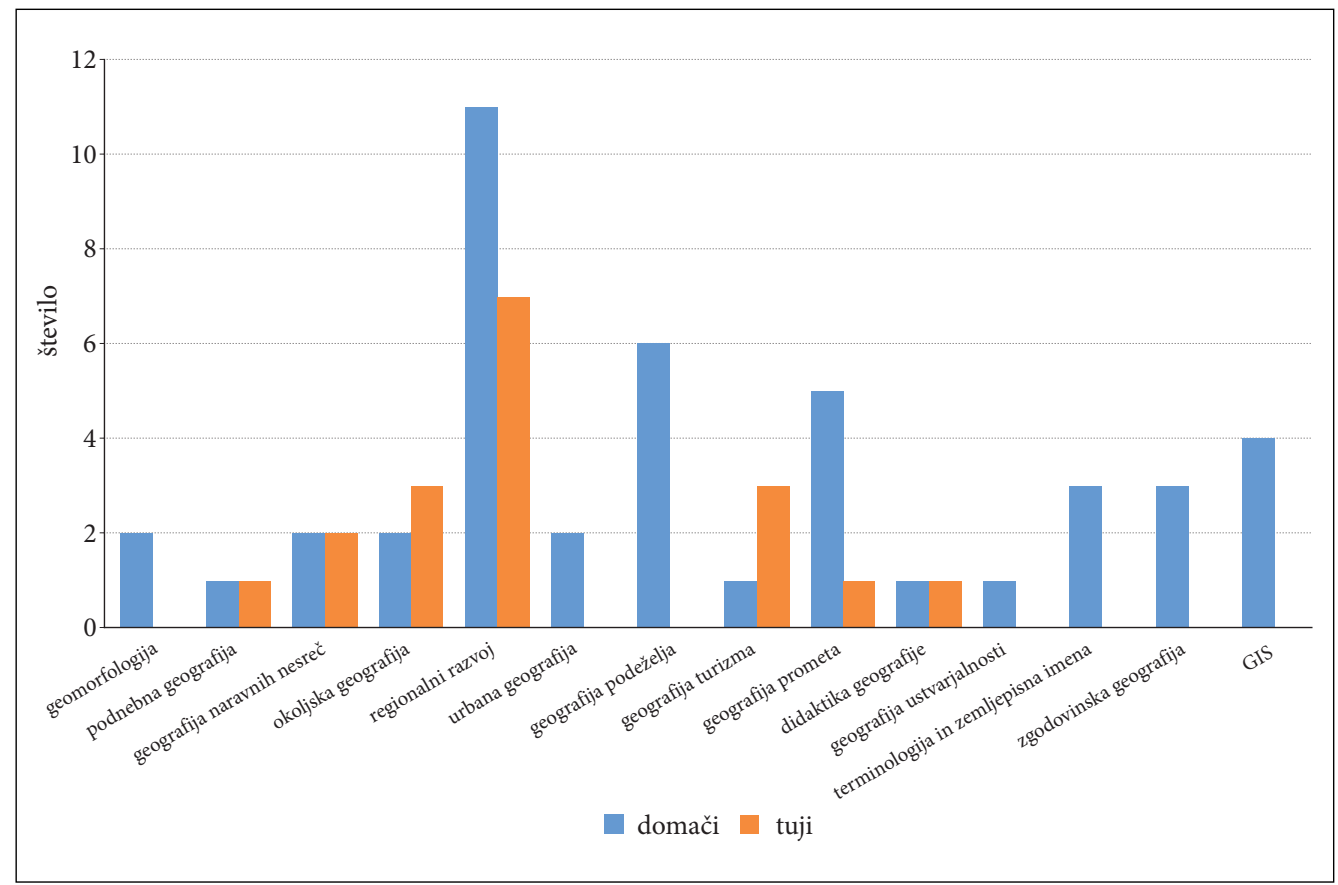

Slika 12: Raziskovalni projekti, ki sta jih financirali Javna agencija za raziskovalno dejavnost Republike Slovenije ali Evropska unija in so potekali na inštitutu od leta 2002, po ožjih geografskih področjih. 
je delež projektov s področja humane geografije skoraj tri četrtine, bolje pa se tu odreže fizična geografije s skoraj šestino projektov (preglednica 2; slika 11). Podrobnejši pogled po geografskih področjih pokaže, da so tako med domačimi kot tujimi projekti prevladovali projekti s področja regionalnega razvoja, katerih delež je bil med domačimi projekti četrtinski, med tujimi pa več kot tretjinski. Več kot desetino projektov so med domačimi predstavljali projekti s področij geografije podeželja in geografije prometa, med tujimi pa s področij geografije naravnih nesreč, okoljske geografije in geografije turizma (preglednica 3; slika 12).

Na sliki 13 vidimo, da je od leta 2002 na inštitutu na leto povprečno potekalo med osem in devet projektov, ki jih je financirala Javna agencija za raziskovalno dejavnost Republike Slovenije. Med letoma 2002 in 2008 je bilo njihovo povprečje blizu deset, med letoma 2009 in 2016 pa nekoliko manj (blizu 8). Najmanj tovrstnih projektov je na inštitutu potekalo v letih 2009 in 2010 (5), največ pa leta 2006 (12).

Leta 2005 sta se na inštitutu začela prva projekta evropskega ozemeljskega sodelovanja. Z letom 2008 začne število takšnih projektov naraščati, kar je odraz uspešnosti pri prijavi projektov v okviru finančne perspektive Evropske unije 2007-2013, ki doseže višek leta 2011 z 12 potekajočimi projekti. Z novo finančno perspektivo Evropske unije 2014-2020 je uspešnost pri prijavi projektov (trenutno) nekoliko upadla. V povprečju je od leta 2005 na inštitutu na leto potekalo med pet in šest evropskih projektov. Ta številčnost finančno močnih evropskih projektov je omogočila že omenjeno kadrovsko krepitev po letu 2008 (slika 10).

Naraščanje števila tujih projektov je pomenilo, da se je financiranje inštituta predvsem po letu 2008 spremenilo. Če je bil delež tujih projektov v proračunu inštituta pred letom 2005 neznaten, je ta do leta 2014 narasel na prek polovico (55\%) (slika 14); zadnji dve leti je zopet nekoliko nižji (16\% leta 2015). S takšnim financiranjem se je inštitut precej razlikoval od načina financiranja na preostalem ZRC SAZU, na katerem so (kot celoti) proračunsko prevladovali domači projekti (v povprečju z $90 \%$; slika 15)

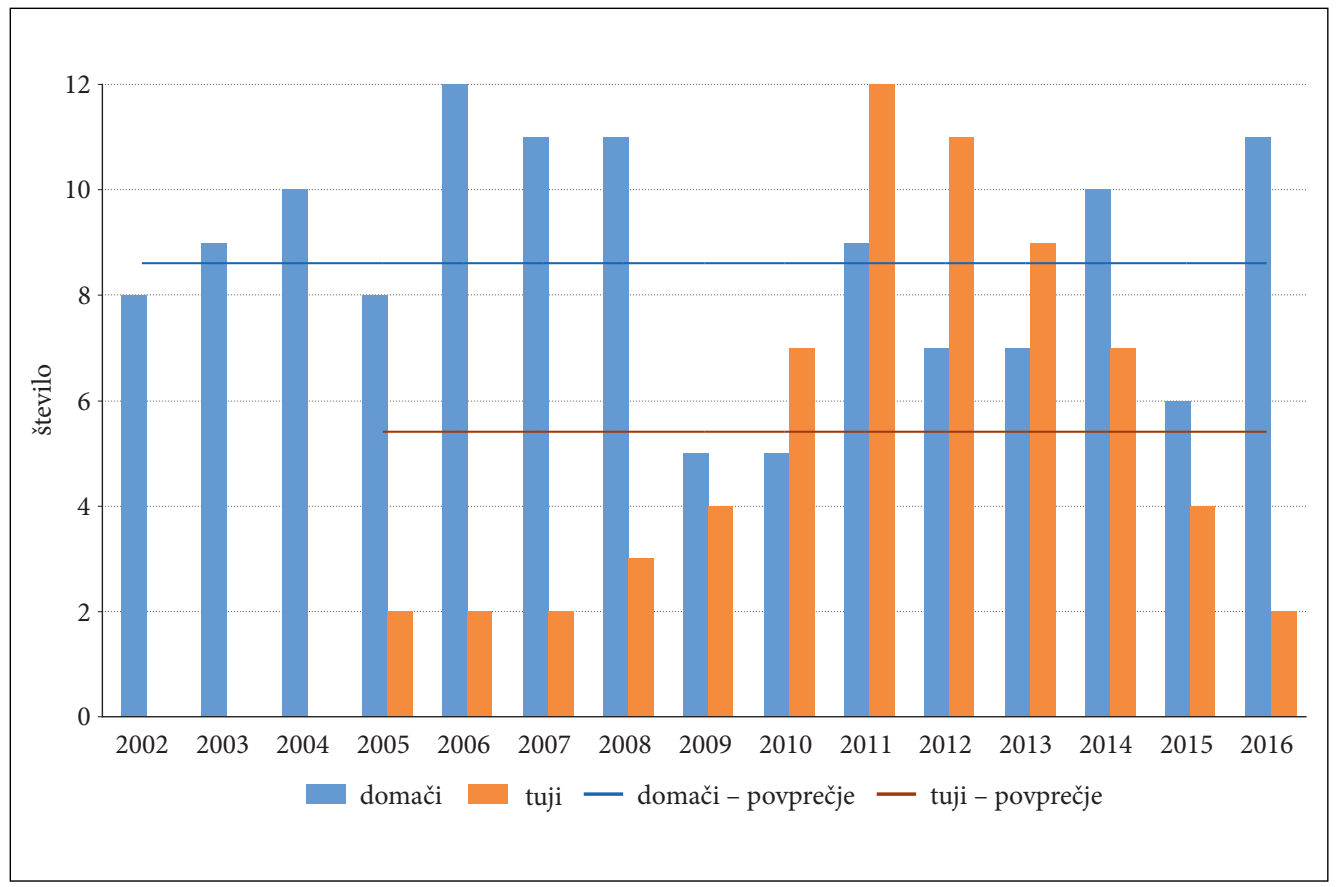

Slika 13: Število raziskovalnih projektov, ki sta jih financirali Javna agencija za raziskovalno dejavnost Republike Slovenije ali Evropska unija in so potekali na inštitutu od leta 2002, po posameznih letih. 
Preglednica 4: Pomembnejši projekti, ki jih je financirala Evropska unija in so omogočili kadrovsko krepitev.

\begin{tabular}{|c|c|c|c|c|}
\hline ime projekta & akronim & $\begin{array}{l}\text { finančni } \\
\text { mehanizem }\end{array}$ & trajanje & $\begin{array}{l}\text { izbran(i) znanstveni } \\
\text { dosežek(i) }\end{array}$ \\
\hline $\begin{array}{l}\text { Data infrastructure for the Alps: } \\
\text { mountain orientated network technology } \\
\text { Podatkovna infrastruktura za Alpe: } \\
\text { gorsko usmerjena mrežna tehnologija }\end{array}$ & DIAMONT & $\begin{array}{l}\text { Evropsko ozemeljsko } \\
\text { sodelovanje, območje } \\
\text { Alp, Evropski sklad } \\
\text { za regionalni razvoj }\end{array}$ & 2005-2008 & $\begin{array}{l}\text { Razpotnik } \\
\text { Visković, } \\
\text { Urbanc in } \\
\text { Nared } 2013\end{array}$ \\
\hline $\begin{array}{l}\text { Raising awareness of values of space } \\
\text { through the process of education } \\
\text { Vrednote prostora in trajnostni } \\
\text { prostorski razvoj: vloga izobraževanja }\end{array}$ & $\begin{array}{l}\text { R.A.V.E. } \\
\text { Space }\end{array}$ & $\begin{array}{l}\text { Evropsko ozemeljsko } \\
\text { sodelovanje, program } \\
\text { CADSES, Evropski } \\
\text { sklad za regionalni } \\
\text { razvoj }\end{array}$ & 2005-2007 & $\begin{array}{l}\text { Urbanc in } \\
\text { Fridl } 2012\end{array}$ \\
\hline $\begin{array}{l}\text { Climate change and its impact } \\
\text { on tourism in the Alpine space } \\
\text { Podnebne spremembe in njihov } \\
\text { vpliv na turizem v alpskem prostoru }\end{array}$ & $\begin{array}{l}\text { Clim- } \\
\text { AlpTour }\end{array}$ & $\begin{array}{l}\text { Evropsko ozemeljsko } \\
\text { sodelovanje, območje } \\
\text { Alp, Evropski sklad } \\
\text { za regionalni razvoj }\end{array}$ & 2008-2011 & $\begin{array}{l}\text { Urbanc in } \\
\text { Pipan 2011; } 2013\end{array}$ \\
\hline $\begin{array}{l}\text { Competitiveness actions and policies } \\
\text { for Alpine cities } \\
\text { Dejavnosti in politike za spodbujanje } \\
\text { konkurenčnosti alpskih mest }\end{array}$ & CAPACities & $\begin{array}{l}\text { Evropsko ozemeljsko } \\
\text { sodelovanje, območje } \\
\text { Alp, Evropski sklad } \\
\text { za regionalni razvoj }\end{array}$ & 2008-2011 & $\begin{array}{l}\text { Nared in } \\
\text { Perko 2010; } \\
\text { Nared in Razpotnik } \\
\text { Visković 2014a; 2014b }\end{array}$ \\
\hline $\begin{array}{l}\text { Social capacity building for natural } \\
\text { hazards: toward more resilient societies } \\
\text { Izboljšanje razmerja med družbo in narav- } \\
\text { nimi nesrečami: prožnejši družbi naproti }\end{array}$ & $\begin{array}{l}\text { CAPHAZ- } \\
\text { Net }\end{array}$ & $\begin{array}{l}\text { 7. okvirni program, } \\
\text { Evropska komisija }\end{array}$ & 2009-2012 & $\begin{array}{l}\text { Komac, Zorn in } \\
\text { Ciglič } 2011\end{array}$ \\
\hline $\begin{array}{l}\text { Improved management of contaminated } \\
\text { aquifers by integration of source tracking, } \\
\text { monitoring tools and decision strategies } \\
\text { Učinkovito upravljanje onesnaženih } \\
\text { vodonosnikov - povezava postopkov za } \\
\text { odkrivanje in nadzor virov onesnaženja } \\
\text { ter ukrepov za izboljšanje stanja }\end{array}$ & INCOME & $\begin{array}{l}\text { Life+ program, } \\
\text { Evropska komisija }\end{array}$ & 2009-2012 & $\begin{array}{l}\text { Jamnik, Janža in } \\
\text { Smrekar } 2014\end{array}$ \\
\hline $\begin{array}{l}\text { Cooperative approaches to transport } \\
\text { challenges in metropolitan regions } \\
\text { Združeni pristopi za reševanje prometnih } \\
\text { izzivov metropolitanskih območij }\end{array}$ & Catch_MR & $\begin{array}{l}\text { Evropsko ozemeljsko } \\
\text { sodelovanje, } \\
\text { INTERREG IVC, } \\
\text { Evropski sklad za } \\
\text { regionalni razvoj }\end{array}$ & 2010-2012 & $\begin{array}{l}\text { Bole in ostali 2012; } \\
\text { Nared in ostali } 2012\end{array}$ \\
\hline $\begin{array}{l}\text { Tool for the territorial strategy } \\
\text { of the MED Space } \\
\text { Orodje za strateško prostorsko } \\
\text { načrtovanje v Sredozemlju }\end{array}$ & OTREMED & $\begin{array}{l}\text { Evropsko ozemeljsko } \\
\text { sodelovanje, Mediteran, } \\
\text { Evropski sklad za } \\
\text { regionalni razvoj }\end{array}$ & $2010-2013$ & Zorn in ostali 2014 \\
\hline $\begin{array}{l}\text { Creative sustainable management, territorial } \\
\text { compatible marketing and environmental } \\
\text { education to be parks }\end{array}$ & 2Bparks & $\begin{array}{l}\text { Evropsko ozemeljsko } \\
\text { sodelovanje, Mediteran, } \\
\text { Evropski sklad za }\end{array}$ & $2010-2013$ & $\begin{array}{l}\text { Smrekar in } \\
\text { Tiran 2013; } \\
\text { Smrekar in }\end{array}$ \\
\hline
\end{tabular}


Ustvarjalno trajnostno gospodarjenje,

regionalni razvoj

ostali 2014

trženje po meri območja in okoljska

vzgoja o parkih

Enhancement of cultural heritage through environmental planning and management Krepitev kulturne dediščine z okoljskim načrtovanjem in upravljanjem

$\begin{array}{llll}\text { CHERPLAN } & \text { Evropsko ozemeljsko } & \text { 2011-2013 } & \text { Nared in Razpotnik } \\ & \text { sodelovanje, } & & \text { Visković 2014 } \\ & \text { jugovzhodna Evropa, } & & \\ & \text { Evropski sklad za } & & \\ & \text { regionalni razvoj } & & \end{array}$

\section{SY_CULTour Evropsko ozemeljsko} sodelovanje, 2011-2014 Bole, Pipan in Komac 2013; jugovzhodna Evropa, Evropski sklad za regionalni razvoj

Synergy of culture and tourism: utilisation of cultural potentials in less favoured rural regions Sinergija kulture in turizma: uporaba kulturnih

vrednot v manj razvitih ruralnih območjih Bole in ostali 2014

Development and application of mitigation and adaptation strategies and measures for counteracting the global urban heat islands Razvoj in uporaba ublažitvenih ter prilagoditvenih strategij in ukrepov za lajšanje globalnega vpliva mestnih toplotnih otokov

Natural hazards without frontiers

Naravne nesreče brez meja
UHI Evropsko ozemeljsko sodelovanje, srednja Evropa, Evropski sklad za regionalni razvoj
2011-2014 Ciglič in

Komac 2014; 2015

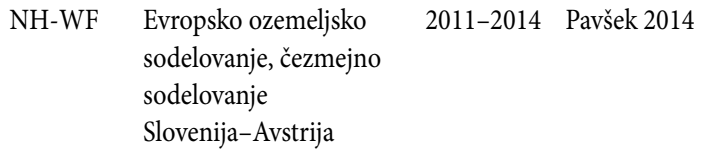

NH-WF Evropsko ozemeljsko 2011-2014 Pavšek 2014 sodelovanje, čezmejno sodelovanje Slovenija-Avstrija

BIOMOT 7. okvirni program, Evropska komisija Horvat in Erhartič 2016 Motivacijska moč ekosistemskih storitev in alternativni načini izražanja vrednosti biodiverzitete

\begin{tabular}{|c|c|c|c|c|}
\hline $\begin{array}{l}\text { Rural-Urban inclusive governance strategies } \\
\text { and tools for the sustainable development } \\
\text { of deeply transforming Alpine territories } \\
\text { Podeželsko-mestne strategije upravljanja in } \\
\text { orodja za trajnostni razvoj spreminjajočih } \\
\text { se alpskih območij }\end{array}$ & Rurbance & $\begin{array}{l}\text { Evropsko ozemeljsko } \\
\text { sodelovanje, območje } \\
\text { Alp, Evropski sklad } \\
\text { za regionalni razvoj }\end{array}$ & $2012-2015$ & $\begin{array}{l}\text { Rus, Razpotnik } \\
\text { Visković in } \\
\text { Nared } 2013\end{array}$ \\
\hline $\begin{array}{l}\text { A wiki for capitalising on spatial-development } \\
\text { projects } \\
\text { Wiki za kapitalizacijo projektov s področja } \\
\text { prostorskega razvoja }\end{array}$ & WIKIAlps & $\begin{array}{l}\text { Evropsko ozemeljsko } \\
\text { sodelovanje, območje } \\
\text { Alp, Evropski sklad } \\
\text { za regionalni razvoj }\end{array}$ & 2013-2014 & $\begin{array}{l}\text { Nared, Razpotnik } \\
\text { Visković in } \\
\text { Komac } 2015\end{array}$ \\
\hline $\begin{array}{l}\text { Inter-cultural dimension for european active } \\
\text { citizenship } \\
\text { Medkulturna razsežnost evropskega } \\
\text { aktivnega državljanstva }\end{array}$ & IDEA-C & $\begin{array}{l}\text { Evropska komisija, } \\
\text { Izvajalska agencija } \\
\text { za izobraževanje, } \\
\text { avdiovizualno področje } \\
\text { in kulturo }\end{array}$ & 2014-2016 & - \\
\hline $\begin{array}{l}\text { Mediteranian culinary heritage experiences: } \\
\text { how to create sustainable tourist destinations } \\
\text { Sredozemska kulinarična dediščinska izkušnja: } \\
\text { kako ustvariti trajnostno turistično destinacijo }\end{array}$ & MEDFEST & $\begin{array}{l}\text { Evropsko ozemeljsko } \\
\text { sodelovanje, Mediteran, } \\
\text { Evropski sklad } \\
\text { za regionalni razvoj }\end{array}$ & 2016-2019 & - \\
\hline
\end{tabular}


Drago Perko, Matija Zorn Sedemdeset let raziskovanj na Geografskem inštitutu Antona Melika ZRC ...

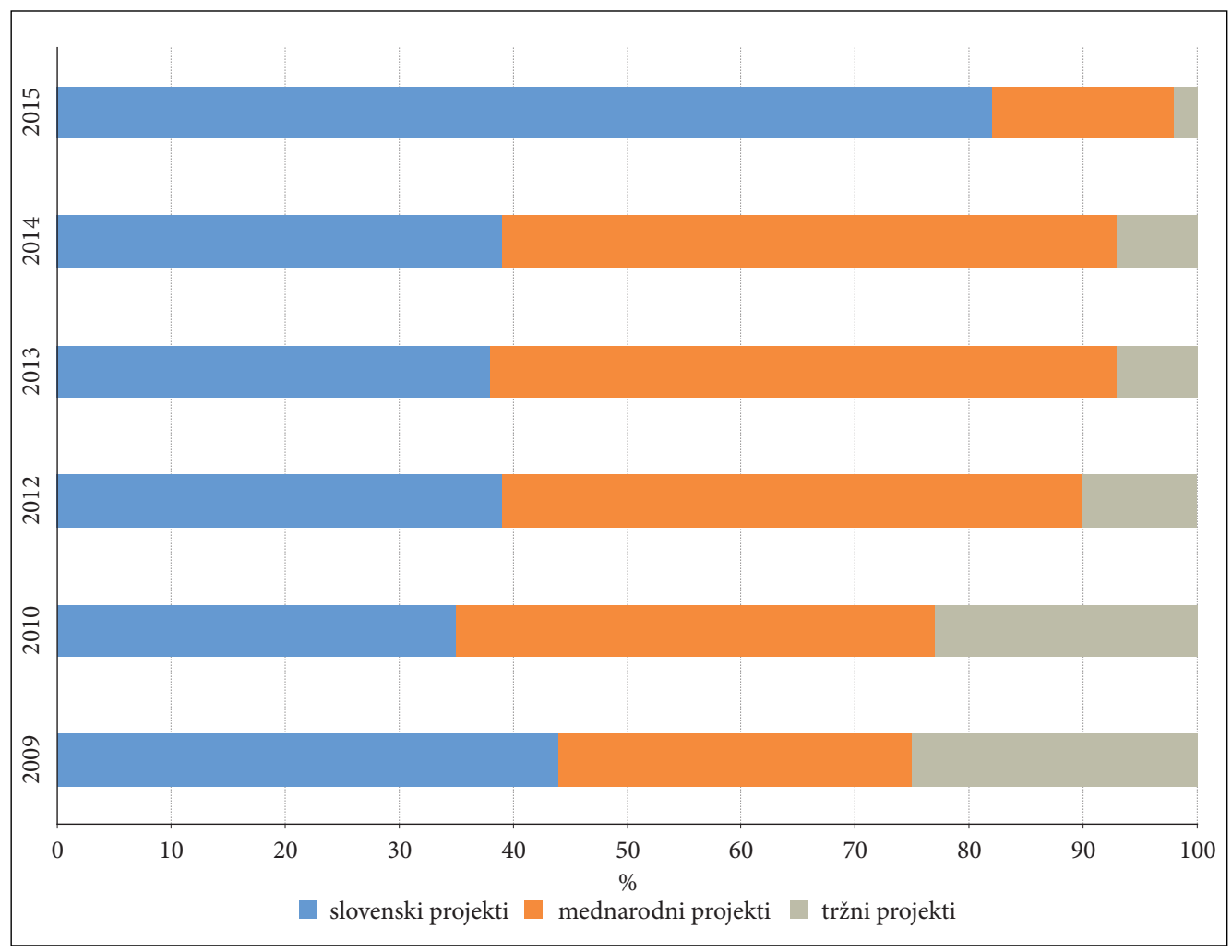

Slika 14: Delež domačih, tujih in tržnih projektov pri financiranju inštituta med letoma 2009 in 2015.

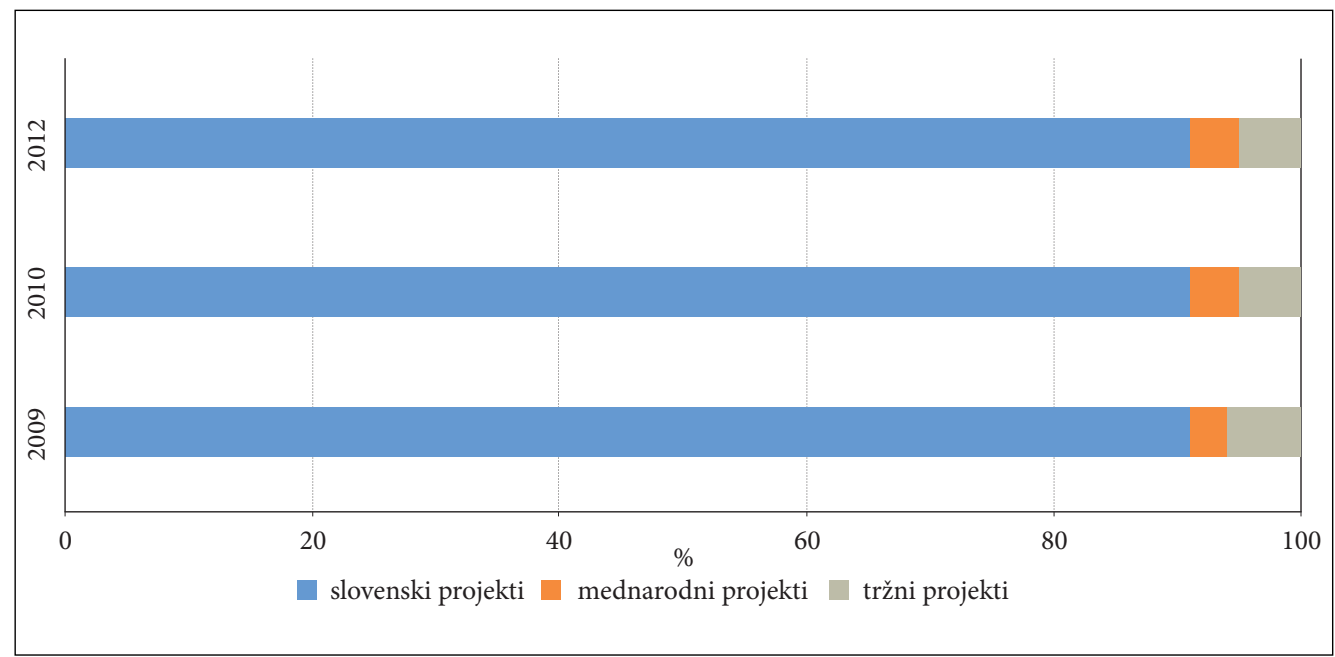

Slika 15: Delež domačih, tujih in tržnih projektov pri financiranju ZRC SAZU v letih 2009, 2010 in 2012. 
Preglednica 5: Članki sodelavcev inštituta, objavljeni v reviji Acta geographica Slovenica od leta 2002 po geografskih področjih.

\begin{tabular}{|c|c|c|}
\hline geografska področja & članki & delež (\%) \\
\hline geomorfologija & $\begin{array}{l}\text { Komac 2003; Hrvatin in Perko 2003; 2005; 2009; Zorn 2009a; 2009b; } \\
\text { Erhartič 2010; Komac, Zorn in Erhartič 2011; Ferk in Lipar 2012; Šegina, } \\
\text { Komac in Zorn 2012; Breg Valjavec 2014; Smrekar, Zorn in Komac 2016; } \\
\text { Šmid Hribar in Ferk 2016; Smrekar, Polajnar Horvat in Erhartič } 2016\end{array}$ & 15 \\
\hline podnebna geografija & Ciglič 2010; Gabrovec in ostali 2013; Marković in ostali 2014 & 3 \\
\hline hidrogeografija & Smrekar 2004 & 1 \\
\hline geografija rastja & Ribeiro, Somodi in Čarni 2016 & 1 \\
\hline $\begin{array}{l}\text { geografija naravnih } \\
\text { nesreč }\end{array}$ & $\begin{array}{l}\text { Zorn 2002; Zorn in Komac 2004; 2007; 2011; Komac in Zorn 2005; } \\
\text { Komac 2009; Komac in ostali 2013; Gavrilov in ostali 2013; Lukić in } \\
\text { ostali 2013; Tosić in ostali } 2014\end{array}$ & 11 \\
\hline okoljska geografija & $\begin{array}{l}\text { Kladnik, Rejec Brancelj in Smrekar 2003; Urbanc in Breg 2005; } \\
\text { Smrekar 2006; 2011; Breg, Kladnik in Smrekar 2007; Polajnar 2008; } \\
\text { Smrekar, Šmid Hribar in Erhartič } 2016\end{array}$ & 7 \\
\hline politična geografija & Pipan 2007; 2008 & 2 \\
\hline ekonomska geografija & $\begin{array}{l}\text { Ravbar, Bole in Nared 2005; Bole 2008; Ravbar 2009; Brozzi in ostali 2015; } \\
\text { Lapuh } 2016\end{array}$ & 5 \\
\hline regionalni razvoj & $\begin{array}{l}\text { Nared 2003; Nared in Ravbar 2003; Bole 2004; 2011; Ravbar 2004; Bole, } \\
\text { Pipan in Komac 2013; Šmid Hribar in Ledinek Lozej 2013; Nared, Erhartič } \\
\text { in Razpotnik Visković 2013; Nared, Razpotnik Visković in Komac 2015a; } \\
\text { 2015b; Nared in ostali } 2015\end{array}$ & 12 \\
\hline geografija prebivalstva & Josipovič 2003; Josipovič in Repolusk 2003 & 2 \\
\hline urbana geografija & Gašperič 2004; Tiran 2016 & 2 \\
\hline geografija podeželja & $\begin{array}{l}\text { Kladnik in Ravbar 2003; Topole in ostali 2006; Hrvatin in Perko 2008; } \\
\text { Razpotnik Visković 2011; } 2015\end{array}$ & 5 \\
\hline raba tal & $\begin{array}{l}\text { Petek 2002; 2005; Petek in Urbanc 2004; Hrvatin, Perko in Petek 2006; } \\
\text { Ciglič in ostali 2012; Ribeiro in ostali } 2013\end{array}$ & 6 \\
\hline $\begin{array}{l}\text { preučevanje kulturnih } \\
\text { pokrajin }\end{array}$ & $\begin{array}{l}\text { Urbanc in ostali 2004; Urbanc 2008; Ažman Momirski in Kladnik 2009; } \\
\text { 2015; Šmid Hribar in Lisec 2011; Urbanc, Gašperič in Kozina 2015; } \\
\text { Smrekar in ostali } 2016\end{array}$ & 7 \\
\hline geografija turizma & Topole 2009; Hose in ostali 2011; Polajnar Horvat 2015; Rančić in ostali 2016 & 4 \\
\hline geografija prometa & Kozina 2010; Bole in ostali 2012 & 2 \\
\hline didaktika geografije & Fridl, Urbanc in Pipan 2009 & 1 \\
\hline geografija ustvarjalnosti & Ravbar 2011 & 1 \\
\hline geografija zdravja & Šprah, Novak in Fridl 2014 & 1 \\
\hline $\begin{array}{l}\text { terminologija in } \\
\text { zemljepisna imena }\end{array}$ & $\begin{array}{l}\text { Kladnik 2007; Kladnik in Pipan 2008; Kladnik in Bole 2012; Klinar in } \\
\text { Geršič } 2014\end{array}$ & 4 \\
\hline zgodovinska kartografija & Urbanc in ostali 2006; Gašperič 2007; 2010 & 3 \\
\hline GIS & Ciglič in Perko 2013; Perko, Hrvatin in Ciglič 2015 & 2 \\
\hline
\end{tabular}


Z gledišča raziskovanja so projekti evropskega ozemeljskega sodelovanja pomenili odmik od le temeljne znanosti, ki je prevladovala v preteklem obdobju in je še značilna za večji del projektov financiranih $\mathrm{s}$ strani Javne agencije za raziskovalno dejavnost Republike Slovenije, v smer aplikativnih raziskav in njih uporabe ter s tem h krepitvi aplikativne geografije (preglednica 4).

Z gledišča kontinuitete raziskav s preteklim obdobjem so stalnica ostali preučevanje ledenikov, skrb za zemljepisna imena ter preučevanje naravnih nesreč (preglednica 1). Leta 2014 je Triglavski ledenik »dobil« rezime skoraj 70-letnih raziskav v monografiji Triglavski ledenik (Gabrovec in ostali 2014), leta 2016 pa tudi razstavo ob 70-letnici preučevanj (Zorn 2016). Zemljepisna imena so deležna stalne pozornosti v okviru Komisije za standardizacijo zemljepisnih imen Vlade Republike Slovenije, ki ima tudi v tem obdobju sedež na inštitutu. V okviru naravnih nesreč se je preučevanje pretežno hidroloških procesov (poplav) razširilo na preučevanje hidro-geomorfnih procesov, predvsem pobočnih procesov (Komac in Zorn 2007; Komac, Natek in Zorn 2008; Zorn 2008; Zorn in Komac 2008), pa tudi na področje družbenih aspektov naravnih nesreč (Komac 2009; Zorn in Komac 2011). V tem oziru so pomembni trienalni simpoziji Naravne nesreče v Sloveniji, ki jih inštitut od leta 2008 prireja skupaj z Upravo Republike Slovenije za zaščito in reševanje ter prevzem urednikovanje revije Ujma (Blaž Komac je od leta 2013 glavni urednik), ki jo izdaja omenjena institucija.

Inštitut poleg tega na dve leti prireja simpozije Geografski informacijski sistemi v Sloveniji (leta 2016 je potekal trinajsti), vsako leto pa simpozije Slovenski regionalni dnevi (leta 2016 je potekal osmi).

Med mejnike v tem obdobju nedvomno sodi uvrstitev inštitutske revije Acte geographice Slovenice v indeks citiranja Science Citation Index Expanded. V indeks so bili vključeni članki od vključno letnika 43 (2003). Z letnikom 49 (2009) je revija dobila faktor vpliva (IF), ki je bil do zdaj najvišji za leto 2011 (IF 1,333) (Komac, Zorn in Perko 2011, 18). Celotno obdobje je revija vključena tudi v bibliografsko bazo Scopus, v okviru katere je imela najvišji faktor vpliva za leto 2012 (SNIP 1,708), ko je bila celo v prvi četrtini revij s svojega področja. $V$ tem obdobju je močno narasla njena mednarodna prepoznavnost, kar se kaže v številu objav tujih avtorjev. Čeprav je revija s tem presegla inštitutske (in tudi nacionalne) okvire, pa je še vedno dober pokazatelj inštitutskega dela, saj ostaja tista publikacija (poleg knjižnih zbirk; poglavje 5), v kateri člani inštituta največkrat predstavljajo svoje raziskave (preglednici 5 in 6; sliki 16 in 17). Od letnika 51 (2011) so izbrane raziskave strnjene o obliki »posebnih številk « oziroma skupine člankov, ki zaokrožujejo neko tematiko, s katero so se člani inštituta ukvarjali v letih pred izdajo. Do vključno letnika 56 (2016) je bilo v devetih številkah predstavljenih pet različnih tematik: geoturizem (Hose in ostali 2011), naravne nesreče (Komac in ostali 2013), kultura in turizem (Bole, Pipan in Komac 2013), trajnostni prostorski razvoj v Alpah (Nared, Razpotnik Visković in Komac 2015) ter ohranjanje dediščine (Smrekar, Zorn in Komac 2016).

Od leta 2002 imajo v reviji med članki sodelavcev inštituta skoraj polovični delež (45\%) teme s področja humane geografije, slabo tretjino predstavljajo teme s področja fizične geografije ( $30 \%)$, dobro četrtino pa teme s področja regionalne geografije (26\%) (preglednica 6; slika 16). Po ožjih področjih geografije imajo v reviji več kot desetinski delež teme povezane z geomorfologijo (15\%), geografijo naravnih nesreč (11\%), regionalnim razvojem (12\%) in geografijo podeželja (skupaj s preučevanjem rabe tal in kulture pokrajine) (19\%) (preglednica 5; slika 17).

Preglednica 6: Članki sodelavcev inštituta, objavljeni v reviji Acta geographica Slovenica od leta 2002 po vejah geografije ( ${ }^{*}$ skupaj je bilo objavljenih sto člankov, a jih šest nismo uvrstili med veje geografije, ker gre bolj za bibliografske prispevke; na sliki 17 so opredeljeni kot ostalo).

\begin{tabular}{lcc}
\hline & število & delež (\%) \\
\hline fizična geografija & 28 & 30 \\
humana geografija & 42 & 45 \\
regionalna geografija & 24 & 26 \\
skupaj & $94^{*}$ & 100 \\
\hline
\end{tabular}


Kratek pregled raziskovalnega dela po letu 2002 sklenimo s skupnim številom znanstvenih objav. Do oddaje tega prispevka so sodelavci inštituta v obravnavanem obdobju objavili prek 350 znanstvenih člankov (355), prek petdeset znanstvenih monografij (53), prek tristo znanstvenih poglavij v monografijah (309), ter blizu osemdeset znanstvenih prispevkov na konferencah (76).

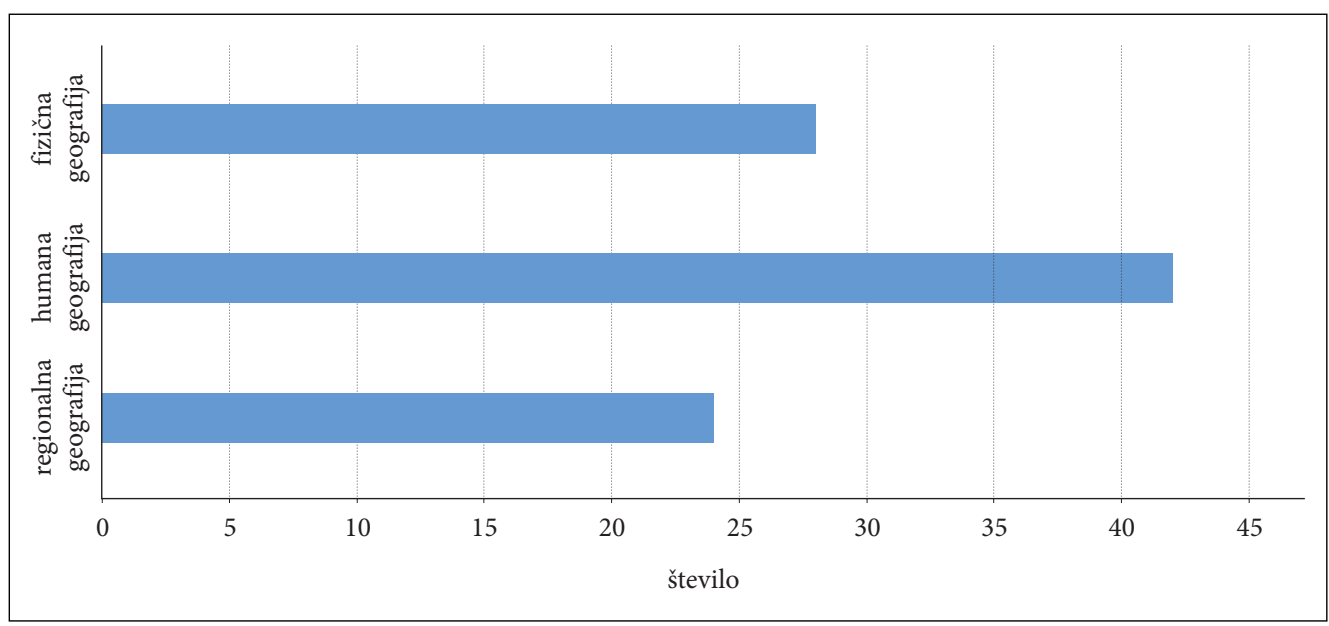

Slika 16: Članki sodelavcev inštituta, objavljeni v reviji Acta geographica Slovenica od leta 2002 po vejah geografije.

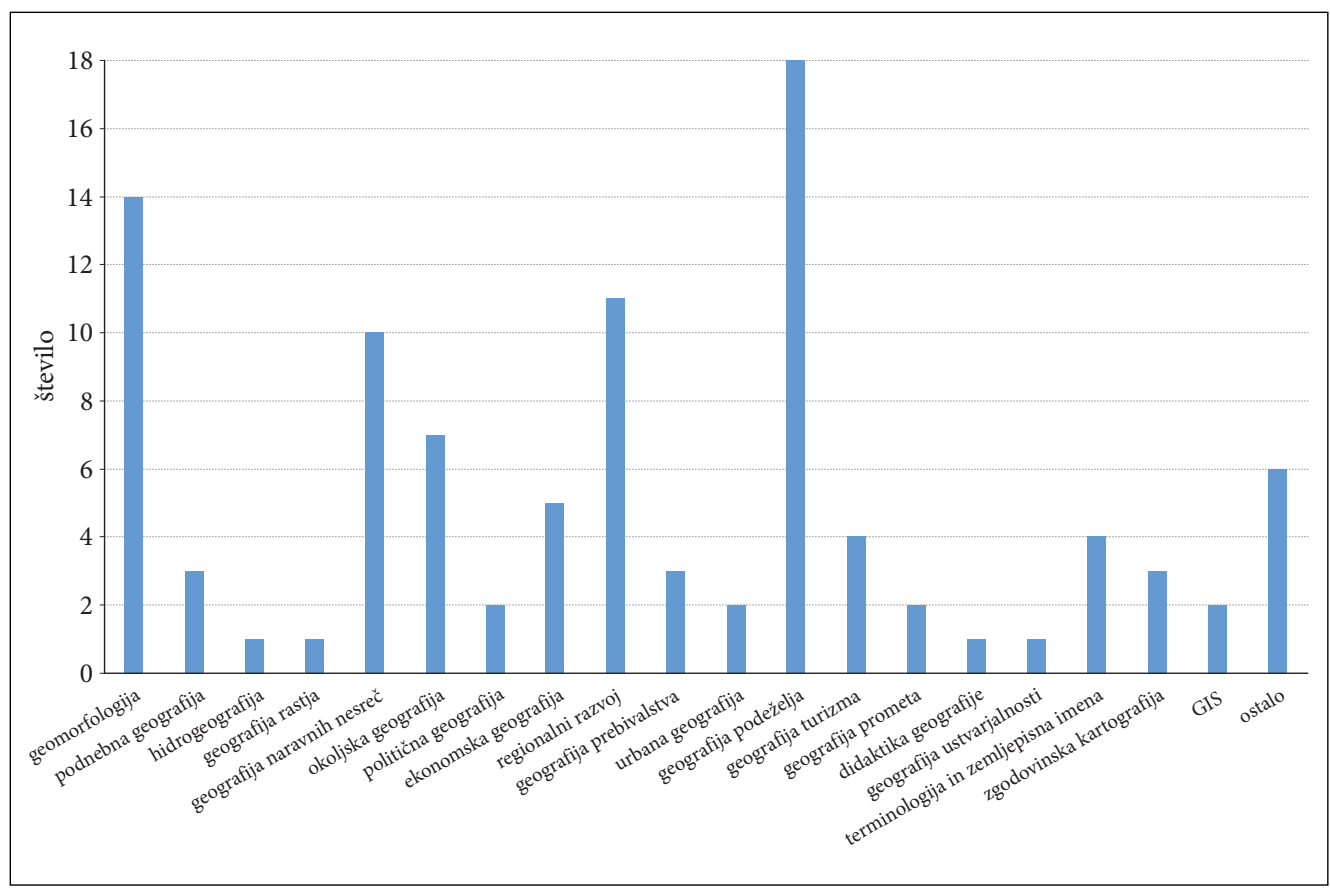

Slika 17: Članki sodelavcev inštituta, objavljeni v reviji Acta geographica Slovenica od leta 2002 po ožjih geografskih področjih. 
Drago Perko, Matija Zorn Sedemdeset let raziskovanj na Geografskem inštitutu Antona Melika ZRC ...

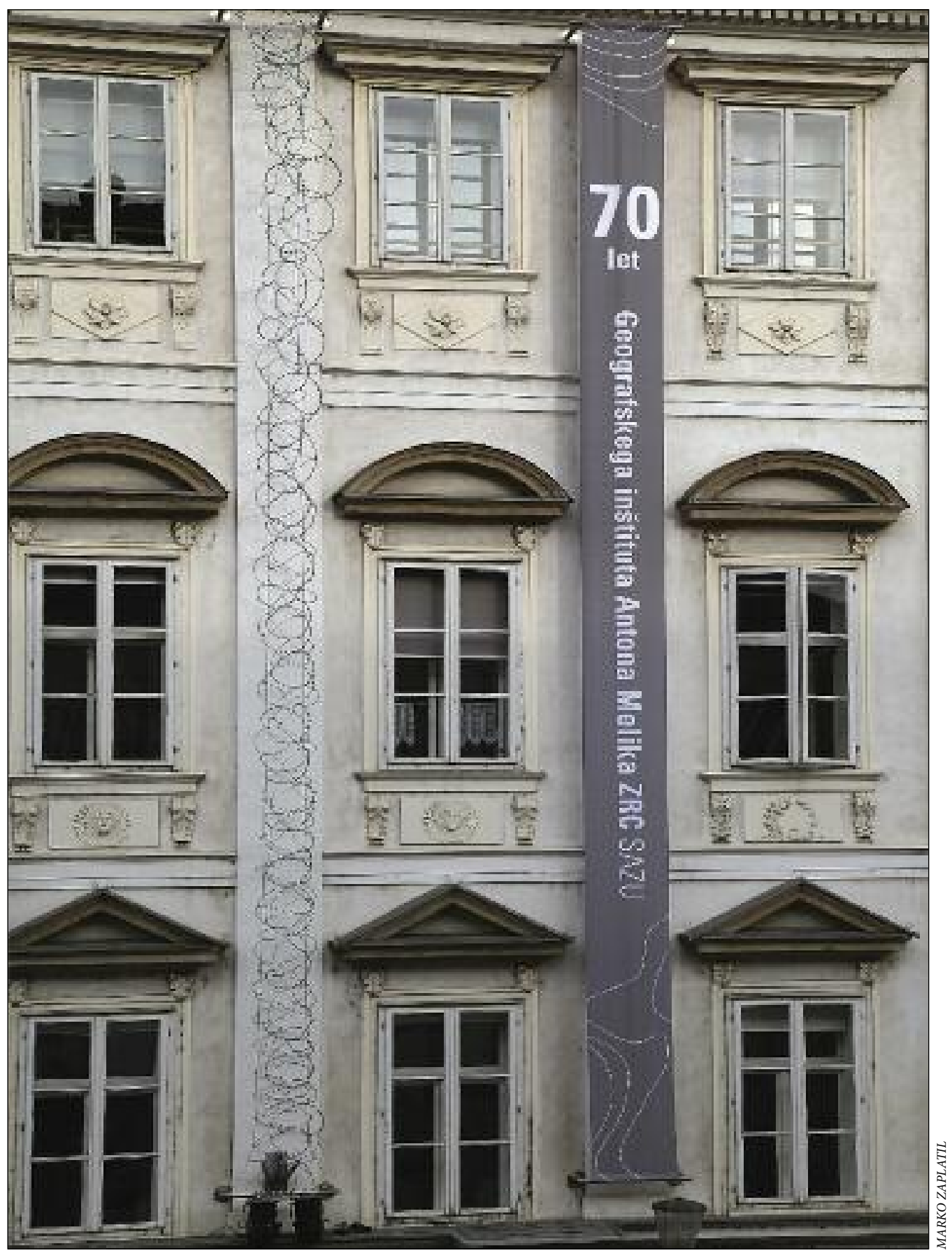

Slika 18: Znanstvenoraziskovalni center Slovenske akademije znanosti in umetnosti je sedemdesetletnico inštituta med drugim obeležil z napisom prek pročelja stavbe na Novem trgu 5. 


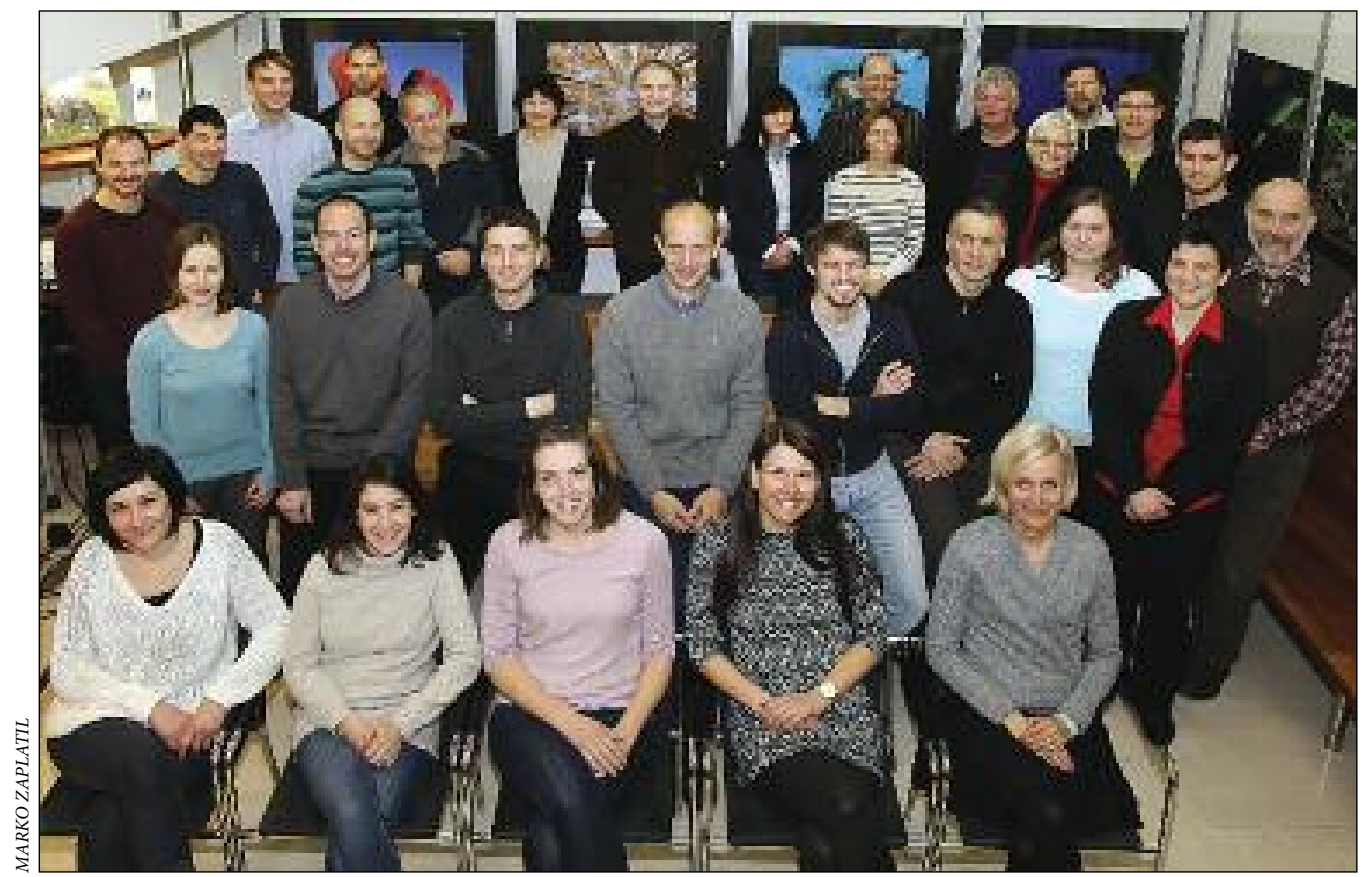

Slika 19: Sodelavci inštituta leta 2016.

\section{Namesto sklepa}

Ob sedemdeseti obletnici je Geografski inštitut Antona Melika Znanstvenoraziskovalnega centra Slovenske akademije znanosti in umetnosti izdal monografijo Terasirane pokrajine, pri kateri so sodelovali vsi člani inštituta in prinaša rezultate triletnega raziskovalnega projekta, ki je potekal med letoma 2011 in 2014 (preglednica 1).

Uvodnik monografije je predstojnik inštituta začel s stavkom: »Terase so nekakšne stopnice od dna proti vrhu, ki dvigajo vrednost terasirane pokrajine, po podobnih stopnicah pa se v časovnem, številčnem in kakovostnem smislu vzpenja tudi naš inštitut in bogati slovensko znanost."

Sredi Uvodnika je zapisal: »... Svetovno odmevnost je inštitut dosegel prav s pripravo nekaterih temeljnih kartografskih del o Sloveniji, na primer velikim Geografskim atlasom Slovenije leta 1998, obsežno monografijo Slovenija - pokrajine in ljudje, prav tako leta 1998, Nacionalnim atlasom Slovenije leta 2001 ob desetletnici samostojnosti Slovenije v slovenskem in angleškem jeziku [Fridl in ostali 2001], zemljevidom Slovenije za National geographic Society leta 2006 [Fridl in Perko 2006], prvim Popisnim atlasom Slovenije leta 2007 [Dolenc in ostali 2007] in atlasom Slovenia in Focus v angleškem jeziku, ki je izšel 1. januarja 2008 ob začetku slovenskega predsedovanja Evropski uniji [Fridl in ostali 2007]. Evropsko razsežnost pa je imela tudi izdaja faksimila zemljevida Ilirskih provinc Gaetana Palme, ki Slovenijo zgodovinsko, geografsko in kartografsko povezuje s Francijo [Gašperič, Orožen Adamič in Šumrada 2012]. $Z$ izdajo zemljevida ob dvestoletnici Ilirskih provinc smo leta 2012 obeležili šestdesetletnico kartografskega oddelka inštituta... «.

Uvodnik je sklenil takole: "... Knjiga Terasirane pokrajine pa nima samo evropskih razsežnosti, ampak predstavlja kmetijske in druge terase po svetu in jih primerja s slovenskimi. Vgraditev kmetijskih teras so generacije ljudi po celem svetu vlagale ogromno dela in z njimi povsem spremenile podobo pokrajine. 
Drago Perko, Matija Zorn Sedemdeset let raziskovanj na Geografskem inštitutu Antona Melika ZRC ...

Podobno smo nekdanji in sedanji raziskovalci geografskega inštituta od skromnih začetkov vsako leto zgradili novo teraso geografskega znanja. Zdaj s sedemdesete terase zadovoljni zremo na nižje terase, naše pretekle dosežke, in se polni upanja veselimo novih, še višjih teras ... " (Perko, Ciglič in Geršič 2016, 3).

\section{Viri in literatura}

Aimée, E., Fridl, J., Orožen Adamič, M., Pavšek, M., Perko, D. (ur.) 1996: Kulturatlas Slowenien. KulturAtlas Europa 6. Gotha, Stuttgart.

Aimée, E., Fridl, J., Orožen Adamič, M., Pavšek, M., Perko, D. (ur.) 1997: Kulturni atlas Slovenija. Tržič. Arhiv predsedstva Slovenske akademije znanosti in umetnosti. Ljubljana.

Ažman Momirski, L., Kladnik, D. 2009: Terasirane pokrajine v Sloveniji. Acta geographica Slovenica 49-1. DOI: http://dx.doi.org/10.3986/AGS49101

Ažman Momirski, L., Kladnik, D. 2015: Terasirana pokrajina v Brkinih. Acta geographica Slovenica 55-1. DOI: http://dx.doi.org/10.3986/AGS.1627

Bole, D. 2004: Dnevna mobilnost delavce v Sloveniji. Acta geographica Slovenica 44-1. DOI: http://dx.doi.org/ 10.3986/AGS44102

Bole, D. 2008: Kulturna industrija kot odraz nove terciarizacije mest. Acta geographica Slovenica 48-2. DOI: http://dx.doi.org/10.3986/AGS48202

Bole, D. 2011: Spremembe v mobilnosti zaposlenih: primerjalna analiza mobilnosti delavcev v največja zaposlitvena središča Slovenije med letoma 2000 in 2009. Acta geographica Slovenica 51-1. DOI: http://dx.doi.org/10.3986/AGS51104

Bole, D., Gabrovec, M., Nared, J., Razpotnik Visković, N. 2012: Načrtovanje javnega potniškega prometa med mestom in regijo na primeru Ljubljane. Acta geographica Slovenica 52-1. DOI: http://dx.doi.org/ 10.3986/AGS52106

Bole, D., Pipan, P., Komac, B. 2013: Cultural values and sustainable rural development: A brief introduction. Acta geographica Slovenica 53-2. DOI: http://dx.doi.org/10.3986/AGS53401

Bole, D., Šmid Hribar, M., Kozina, J., Pipan, P. (ur.) 2014: Sinergija kulture in turizma za razvoj podeželskih območij. Ljubljana.

Breg Valjavec, M. 2014: Odkrivanje prikritih odlagališč odpadkov v prodni ravnini z geomorfometrično analizo in LiDAR DTM. Acta geographica Slovenica 54-1. DOI: http://dx.doi.org/10.3986/AGS54106

Breg, M., Kladnik, D., Smrekar, A. 2007: Odlagališča odpadkov na vodovarstvenem območju Ljubljanskega polja, glavnem viru oskrbe Ljubljane s pitno vodo. Acta geographica Slovenica 47-1. DOI: http://dx.doi.org/10.3986/AGS47104

Brozzi, R., Lapuh, L., Nared, J., Streifeneder, T. 2015: Towards more resilient economies in Alpine regions. Acta geographica Slovenica 55-2. DOI: http://dx.doi.org/10.3986/AGS.916

Ciglič, R. 2010: Informativni vrednosti nadmorske višine in višinske razlike za ponazoritev termalnega pasu. Acta geographica Slovenica 50-2. DOI: http://dx.doi.org/10.3986/AGS50201

Ciglič, R., Hrvatin, M., Komac, B., Perko, D. 2012: Kras kot kazalnik za določanje manj primernih območij za kmetijstvo. Acta geographica Slovenica 52-1. DOI: http://dx.doi.org/10.3986/AGS52103

Ciglič, R., Komac, B. 2014: Urban heat island atlas: a web tool for the determination and mitigation of urban heat island effects. Geographia Polonica 87-4.

Ciglič, R., Komac, B. 2015: Central-European urban heat island atlas. Ljubljana. Medmrežje: http://gismo.zrc-sazu.si/flexviewers/UHIAtlas/ (2.10.2016).

Ciglič, R., Perko, D. 2013: Pokrajinske vroče točke Evrope. Acta geographica Slovenica 53-1. DOI: http://dx.doi.org/10.3986/AGS53106

Dolenc, D., Fridl, J., Kladnik, D., Perko, D., Repolusk, P. (ur.) 2007: Popisni atlas Slovenije 2002. Ljubljana.

Erhartič, B. 2010: Vrednotenje geomorfološke dediščine. Acta geographica Slovenica 50-2. DOI: http://dx.doi.org/10.3986/AGS50206 
Ferk, M., Lipar, M. 2012: Eogenetske jame v pleistocenskem karbonatnem konglomeratu v Sloveniji. Acta geographica Slovenica 52-1. DOI: http://dx.doi.org/10.3986/AGS52101

Fridl, J., Kladnik, D., Orožen Adamič, M., Perko, D. (ur.) 1998: Geografski atlas Slovenije - država $\mathrm{v}$ prostoru in času. Ljubljana.

Fridl, J., Kladnik, D., Orožen Adamič, M., Perko, D., Urbanc, M. (ur.) 2005: Atlant. Ljubljana

Fridl, J., Kladnik, D., Orožen Adamič, M., Perko, D., Zupančič, J. (ur.) 2001: Nacionalni atlas Slovenije. Ljubljana.

Fridl, J., Kladnik, D., Pavšek, M., Perko, D., Repolusk, P., Urbanc, M., Orožen Adamič, M. (ur.) 2007: Slovenia in focus. Ljubljana.

Fridl, J., Perko, D., 2006: Slovenija. Zemljevid v merilu 1:400.000. Ljubljana.

Fridl, J., Urbanc, M., Pipan, P. 2009: Pomen učiteljevega zaznavanja prostora v izobraževalnem procesu. Acta geographica Slovenica 49-2. DOI: http://dx.doi.org/10.3986/AGS49205

Gabrovec, M., Hrvatin, M., Komac, B., Ortar, J., Pavšek, M., Topole, M., Triglav Čekada, M., Zorn, M. 2014: Triglavski ledenik. Geografija Slovenije 30.

Gabrovec, M., Ortar, J., Pavšek, M., Zorn, M., Triglav Čekada, M. 2013: Triglavski ledenik med letoma 1999 in 2012: Acta geographica Slovenica 53-2. DOI: http://dx.doi.org/10.3986/AGS53202

Gams, I. 1955: Snežni plazovi v Sloveniji v zimah 1950-1954. Geografski zbornik 3.

Gams, I. 1959: Geomorfologija in izraba tal v Pomurju. Geografski zbornik 5.

Gams, I. 1960: O višinski meji naseljenosti, ozimine, gozda in snega v slovenskih gorah. Geografski vestnik 32. Gams, I. 1961a: H geomorfologiji Bele krajine. Geografski zbornik 6.

Gams, I. 1961b: Snežišča v Julijskih Alpah. Geografski zbornik 6.

Gams, I., Natek, K. 1981: Geomorfološka karta 1:100.000 in razvoj reliefa v Litijski kotlini. Geografski zbornik 21.

Gašperič, P. 2004: Širitev Ljubljane na Ljubljansko barje. Acta geographica Slovenica 44-2. DOI: http://dx.doi.org/10.3986/AGS44201

Gašperič, P. 2007: Kartografske upodobitve Slovenije skozi čas. Acta geographica Slovenica 47-2. DOI: http://dx.doi.org/10.3986/AGS47203

Gašperič, P. 2010: O Zemljevidu Ilirskih provinc avtorja Gaetana Palme iz leta 1812. Acta geographica Slovenica 50-2. DOI: http://dx.doi.org/10.3986/AGS50205

Gašperič, P., Orožen Adamič, M., Šumrada, J. 2012: Zemljevid Ilirskih provinc iz leta $1812=$ Carte des Provinces illyriennes de 1812. Ljubljana.

Gavrilov, M. B., Marković, S. B., Zorn, M., Komac, B., Lukić, T., Milošević, M., Janićević, S. 2013: Is hail suppression useful in Serbia? - General review and new results. Acta geographica Slovenica 53-1. DOI: http://dx.doi.org/10.3986/AGS53302

Hose, T. A., Marković, S. B., Komac, B., Zorn, M. 2011: Geotourism - a short introduction. Acta geographica Slovenica 51-2. DOI: http://dx.doi.org/10.3986/AGS51301

Hrvatin, M., Perko, D. 2003: Razgibanost površja in raba tal v Sloveniji. Acta geographica Slovenica 43-2. DOI: http://dx.doi.org/10.3986/AGS43202

Hrvatin, M., Perko, D. 2005: Razlike med stometrskim in petindvajsetmetrskim digitalnim modelom višin glede na tipe reliefa v Sloveniji. Acta geographica Slovenica 45-1. DOI: http://dx.doi.org/ 10.3986/AGS45101

Hrvatin, M., Perko, D. 2008: Pokrajinske značilnosti skupnih zemljišč v Sloveniji. Acta geographica Slovenica 48-1. DOI: http://dx.doi.org/10.3986/AGS48101

Hrvatin, M., Perko, D. 2009: Primernost Hammondove metode za določanje enot oblikovanosti površja v Sloveniji. Acta geographica Slovenica 49-2. DOI: http://dx.doi.org/10.3986/AGS49204

Hrvatin, M., Perko, D., Petek, F. 2006: Raba tal na izbranih erozijsko ogroženih območjih terciarnih gričevij v Sloveniji. Acta geographica Slovenica 46-1. DOI: http://dx.doi.org/10.3986/AGS46103

Ilešič, S. (ur.) 1976: Geografski zbornik 15.

Ilešič, S. 1946: Pregled nove književnosti o naših mejnih vprašanjih. Geografski vestnik 18.

Ilešič, S. 1950: Slovenska geografija v 30 letih ljubljanske univerze. Geografski vestnik 22. 
Drago Perko, Matija Zorn Sedemdeset let raziskovanj na Geografskem inštitutu Antona Melika ZRC ...

Jamnik, B., Janža, M., Smrekar, A. (ur.) 2014: Skrb za pitno vodo. Geografija Slovenije 31. Ljubljana. Josipovič, D. 2003: Geografski dejavniki rodnosti prebivalstva. Acta geographica Slovenica 43-1. DOI: http://dx.doi.org/10.3986/AGS43104

Josipovič, D., Repolusk, P. 2003: Demografske značilnosti Romov v Prekmurju. Acta geographica Slovenica 43-1. DOI: http://dx.doi.org/10.3986/AGS43105

Kladnik, D. 2007: Značilnosti rabe eksonimov v nekaterih evropskih jezikih. Acta geographica Slovenica 47-2. DOI: http://dx.doi.org/10.3986/AGS47203

Kladnik, D. 2009: Prispevek k pomenski razmejitvi terminov endonim in eksonim. Acta geographica Slovenica 49-2. DOI: http://dx.doi.org/10.3986/AGS49206

Kladnik, D., Bole, D. 2012: O življenju slovenskih eksonimov in njihovem poznavanju v strokovni javnosti. Acta geographica Slovenica 52-2. DOI: http://dx.doi.org/10.3986/AGS52204

Kladnik, D., Pipan, P. 2008: Piranski zaliv ali Savudrijska vala? Primer problematičnega ravnanja z zemljepisnimi imeni. Acta geographica Slovenica 48-1. DOI: http://dx.doi.org/10.3986/AGS48103

Kladnik, D., Ravbar, M. 2003: Pomen členitev podeželja pri spodbujanju regionalnega razvoja. Acta geographica Slovenica 43-1. DOI: http://dx.doi.org/10.3986/AGS43101

Kladnik, D., Rejec Brancelj, I., Smrekar, A. 2003: Gnojni objekti kot nevarni točkovni viri obremenjevanja podtalnice Ljubljanskega polja. Acta geographica Slovenica 43-2. DOI: http://dx.doi.org/ 10.3986/AGS43204

Klinar, K., Geršič, M. 2014: Traditional house names as part of cultural heritage. Acta geographica Slovenica 54-2. DOI: http://dx.doi.org/10.3986/AGS54409

Komac, B. 2003: Dolomitni relief na območju Žibrš. Acta geographica Slovenica 43-2. DOI: http://dx.doi.org/ 10.3986/AGS43201

Komac, B. 2009: Družbenogeografski spomin in naravnogeografski spomin na naravne nesreče. Acta geographica Slovenica 49-1. DOI: http://dx.doi.org/10.3986/AGS49107

Komac, B., Natek, K., Zorn, M. 2008: Geografski vidiki poplav v Sloveniji. Geografija Slovenije 20. Ljubljana.

Komac, B., Zorn, M. 2005: Erozija prsti na kmetijskih zemljiščih v Sloveniji - meritve žlebične erozije v dolini Besnice. Acta geographica Slovenica 45-1. DOI: http://dx.doi.org/10.3986/AGS45103

Komac, B., Zorn, M. 2007: Pobočni procesi in človek. Geografija Slovenije 15. Ljubljana.

Komac, B., Zorn, M., Ciglič, R. 2011: Izobraževanje o naravnih nesrečah v Evropi. Georitem 18. Ljubljana.

Komac, B., Zorn, M., Erhartič, B. 2011: Loss of natural heritage from the geomorphological perspective - Do geomorphic processes shape or destroy the natural heritage? Acta geographica Slovenica 51-2. DOI: http://dx.doi.org/10.3986/AGS51306

Komac, B., Zorn, M., Gavrilov, M. B., Marković, S. B. 2013: Natural hazards - some introductory thoughts. Acta geographica Slovenica 53-1. DOI: http://dx.doi.org/10.3986/AGS53300

Komac, B., Zorn, M., Perko, D. 2011: Odsev dogajanja v slovenski in svetovni geografiji. Delo 53-185 (11.8.2011).

Kozina, J. 2010: Prometna dostopnost do regionalnih središč v Sloveniji. Acta geographica Slovenica 50-2. DOI: http://dx.doi.org/10.3986/AGS50203

Lapuh, L. 2016: Merjenje vpliva recesije in sposobnosti okrevanja slovenskih statističnih regij. Acta geographica Slovenica 56-2. DOI: http://dx.doi.org/10.3986/AGS.764

Letopisi Slovenske akademije znanosti in umetnosti 1 do 47. Ljubljana, 1948-1996.

Lukić, T., Gavrilov, M. B., Marković, S. B., Komac, B., Zorn, M., Mlađan, D., Đorđević, J., Milanović, M., Vasiljević, D. A., Vujičić, M. D., Kuzmanović, B., Prentović, R. 2013: Classification of natural disasters between the legislation and application: experience of the Republic of Serbia. Acta geographica Slovenica 53-1. DOI: http://dx.doi.org/10.3986/AGS53301

Marković, S. B., Ruman, A., Gavrilov, M. B., Stevens, T., Zorn, M., Komac, B., Perko, D. 2014: Modelling of the Aral and Caspian seas drying out influence to climate and environmental changes. Acta geographica Slovenica 54-1. DOI: http://dx.doi.org/10.3986/AGS54304

Melik, A. 1945: Druga svetovna vojna in mi geografi. Geografski vestnik 17. 
Melik, A. 1946: Ljubljansko mostiščarsko jezero in dediščina po njem. Dela SAZU 5. Ljubljana.

Melik, A. 1950: Planine v Julijskih Alpah. Dela Inštituta za geografijo 1. Ljubljana.

Melik, A. 1954: Nova glaciološka dognanja v Julijskih Alpah. Geografski zbornik 2.

Melik, A. 1955a: Kraška polja Slovenije v pleistocenu. Dela Inštituta za geografijo 3. Ljubljana.

Melik, A. 1955b: Nekaj glacioloških opažanj iz Zgornje Doline. Geografski zbornik 5.

Melik, A. 1956: Izvenalpske planine na Slovenskem. Geografski zbornik 4.

Melik, A. 1959: Nova geografska dognanja na Trnovskem gozdu. Geografski zbornik 5.

Melik, A. 1961: Vitranc, Zelenci in Bovško, Geomorfološke študije iz zahodnih Julijskih Alp. Geografski zbornik 6.

Meze, D. 1955: Ledenik na Triglavu in na Skuti. Geografski zbornik 3.

Meze, D. 1959: Pozeba oljke v Primorju leta 1956. Geografski zbornik 5.

Meze, D. 1960: Nekaj o hribovskih kmetijah v Gornji Savinjski dolini. Geografski vestnik 32.

Meze, D. 1963a: H geomorfologiji Voglajnske pokrajine in Zgornjega Sotelskega. Geografski zbornik 8.

Meze, D. 1963b: Samotne kmetije na Solčavskem. Geografski zbornik 8.

Meze, D. 1965: Samotne kmetije v Lučki pokrajini. Geografski zbornik 9.

Meze, D. 1966: Gornja Savinjska dolina, Nova dognanja o geomorfološkem razvoju pokrajine. Dela SAZU 20. Ljubljana.

Meze, D. 1969: Hribovske kmetije v vzhodnem delu Gornje Savinjske doline. Geografski zbornik 11.

Meze, D. 1974: Porečje Kokre v pleistocenu. Geografski zbornik 14.

Meze, D. 1977: Poplavna področja v Gornji Savinjski dolini. Geografski zbornik 17.

Meze, D. 1979: Hribovske kmetije v Gornji Savinjski dolini po letu 1967. Geografski zbornik 19.

Meze, D. 1980a: Osnovne smernice za geografsko proučevanje hribovskih kmetij na Slovenskem. Geografski vestnik 52.

Meze, D. 1980b: Poplavna področja v Grosupeljski kotlini. Geografski zbornik 20.

Meze, D. 1981: Hribovske kmetije ob Kokri in v Krvavškem predgorju. Geografski zbornik 21.

Meze, D. 1982: Poplavna področja v porečju Rašice z Dobrepoljami. Geografski zbornik 22.

Meze, D. 1983: Hribovske kmetije med dolinama Kokre in Drage. Geografski zbornik 23.

Meze, D. 1985: Hribovske kmetije v Polhograjskem hribovju, bližnji okolici in sosednjih Rovtah. Geografski zbornik 25.

Meze, D. 1986: Hribovske kmetije v Selški dolini. Loški razgledi 33. Škofja Loka.

Meze, D. 1987: Hribovske kmetije na Idrijskem in Cerkljanskem. Geografski zbornik 27.

Meze, D. 1988: Kmetije na Šentviški planoti in v Trebuši. Geografski zbornik 28.

Nared, J. 2003: Zakonodaja na področju regionalne politike v Sloveniji in analiza njenih učinkov v prostoru. Acta geographica Slovenica 43-1. DOI: http://dx.doi.org/10.3986/AGS43103

Nared, J., Bole, B., Gabrovec, M., Geršič, M., Goluža, M., Razpotnik Visković, N., Rus P. 2012: Celostno načrtovanje javnega potniškega prometa v Ljubljanski urbani regiji. Georitem 20. Ljuljana.

Nared, J., Erhartič, B., Razpotnik Visković, N. 2013: Including development topics in a cultural heritage management plan: mercury heritage in Idrija. Acta geographica Slovenica 53-2. DOI: http://dx.doi.org/ 10.3986/AGS53404

Nared, J., Perko, D. (ur.) 2010: Na prelomnici: Razvojna vprašanja občine Idrija. CAPAcities 1. Ljubljana.

Nared, J., Ravbar, M. 2003: Izhodišča za spremljanje in vrednotenje regionalne politike v Sloveniji. Acta geographica Slovenica 43-1. DOI: http://dx.doi.org/10.3986/AGS43102

Nared, J., Razpotnik Visković, N. (ur.) 2014a: Upravljanje območij s kulturno dediščino. CAPAcities 2. Ljubljana.

Nared, J., Razpotnik Visković, N. (ur.) 2014b: Izbrani primeri upravljanja območij s kulturno dediščino. CAPAcities 3. Ljubljana.

Nared, J., Razpotnik Visković, N. 2014: Managing cultural heritage sites in Southeastern Europe. Ljubljana. 
Nared, J., Razpotnik Visković, N., Cremer-Schulte, D., Brozzi, R., Cortines Garcia, F. 2015: Achieving sustainable spatial development in the Alps through participatory planning. Acta geographica Slovenica 55-2. DOI: http://dx.doi.org/10.3986/AGS.1631

Nared, J., Razpotnik Visković, N., Komac, B. 2015a: Sustainable spatial development in the Alps. Acta geographica Slovenica 55-1. DOI: http://dx.doi.org/10.3986/AGS.1969

Nared, J., Razpotnik Visković, N., Komac, B. 2015b: The Alps: A physical geography, political, and program framework. Acta geographica Slovenica 55-1. DOI: http://dx.doi.org/10.3986/AGS.1970

Natek, K. 1983a: Razvoj reliefa in izraba tal v Ložniškem gričevju. Geografski zbornik 23.

Natek, K. 1983b: Hudi nevihti s točo na celjskem območju in na Gorenjskem dne 29. 6. 1982. Geografski zbornik 23.

Natek, K. 1984: Suša 1983 v Sloveniji. Geografski zbornik 24.

Natek, K. 1986: Projekt Splošna geomorfološka karta Jugoslavije v merilu 1 : 100.000 in kartiranje kraškega površja. Acta carsologica 14-15.

Natek, K. 1989: Vloga usadov pri geomorfološkem preoblikovanju Voglajnskega gričevja. Geografski zbornik 29.

Natek, K. 1990: Geomorfološke značilnosti usadov v Halozah. Ujma 4.

Natek, M. 1978: Poplavna območja v Spodnji Savinjski dolini. Geografski zbornik 18.

Natek, M. 1983: Hribovske kmetije v vzhodnem delu Dobroveljske planote. Geografski zbornik 23.

Natek, M. 1987: Hribovske kmetije v pokrajinski strukturi Mežiške doline. Teorija in metodologija regionalne geografije. Ljubljana.

Natek, M. 1992a: Nekateri geografski vidiki poplavnih območij na Slovenskem. Poplave v Sloveniji. Ljubljana.

Natek, M. 1992b: Prebivalstvo hribovskih kmetij na Pohorju. Socialna geografija v teoriji in praksi. Ljubljana.

Natek, M., Perko, D. 1999: 50 let Geografskega inštituta Antona Melika ZRC SAZU. Geografija Slovenije 1. Ljubljana.

Orožen Adamič, M. 1978: Posledice potresov leta 1976 v Sloveniji. Geografski zbornik 18.

Orožen Adamič, M. 1979: Geografske značilnosti poplavnega sveta ob Dragonji in Drnici. Geografski zbornik 19.

Orožen Adamič, M. 1982: The Effects of the 1976 Earthquake in the Soča River Basin. Social and Economic Aspects of Earthquakes. New York.

Orožen Adamič, M. 1983: Neurja in poplave Poljanske Sore v letu 1982. Geografski zbornik 23.

Orožen Adamič, M. 1987: Hribovske kmetije na severni strani Poljanske doline. Geografski zbornik 27.

Orožen Adamič, M., Kunaver, J. 1978: Zgornje Posočje po potresu. Zgornje Posočje, Zbornik 10. zborovanja slovenskih geografov. Ljubljana.

Orožen Adamič, M., Perko, D., Kladnik, D. (ur.) 1995: Krajevni leksikon Slovenije. Ljubljana.

Orožen Adamič, M., Šifrer, M. 1984: Učinki viharja 9.-11. februarja 1984 v Sloveniji. Geografski zbornik 24.

Pavšek, M. (ur.) 2014: Snežna sezona 2012/2013 v Sloveniji: vremenske in snežne razmere ter lavinske nesreče in dogodki: pregled, analiza in sklepi. Ljubljana.

Perko, D. 1991: Digitalni model reliefa kot osnova za geografski informacijski sistem. Geodetski vestnik 35-4.

Perko, D. 1992a: Ogroženost Slovenije zaradi naravnih nesreč. Ujma 6.

Perko, D. 1992b: Poplave kot sestavina splošne ogroženosti Slovenije zaradi naravnih nesreč. Poplave v Sloveniji. Ljubljana.

Perko, D., Ciglič, R., Geršič, M. (ur.) 2016: Terasirane pokrajine. Ljubljana.

Perko, D., Hrvatin, M., Ciglič, R. 2015: Metodologija naravne pokrajinske tipizacije Slovenije. Acta geographica Slovenica 55-2. DOI: http://dx.doi.org/10.3986/AGS.1938

Perko, D., Križnar, N. 1997: Pokrajine v Sloveniji. Podobe znanosti 6. Video. Ljubljana.

Perko, D., Orožen Adamič, M. (ur.) 1998: Slovenija - pokrajine in ljudje. Ljubljana.

Perko, D., Zorn, M. 2010: Zgodovina knjižne zbirke GIS v Sloveniji. Geografski informacijski sistemi v Sloveniji 2009-2010. Ljubljana. 
Petek, F. 2002: Metodologija vrednotenja sprememb rabe tal v Sloveniji med letoma 1895 in 1999. Geografski zbornik 42 .

Petek, F. 2005: Tipologija slovenskega alpskega sveta s poudarkom na rabi in spremembah rabe tal. Acta geographica Slovenica 45-1. DOI: http://dx.doi.org/10.3986/AGS45102

Petek, F., Urbanc, M. 2004: Franciscejski kataster kot ključ za razumevanje kulturne pokrajine v Sloveniji v 19. stoletju. Acta geographica Slovenica 44-1. DOI: http://dx.doi.org/10.3986/AGS44104

Pipan, P. 2007: Čezmejno sodelovanje med Slovenijo in Hrvaško v Istri po letu 1991. Acta geographica Slovenica 47-2. DOI: http://dx.doi.org/10.3986/AGS47204

Pipan, P. 2008: Mejni spor med Hrvaško in Slovenijo ob spodnjem toku reke Dragonje. Acta geographica Slovenica 48-2. DOI: http://dx.doi.org/10.3986/AGS48205

Polajnar Horvat, K. 2015: Možnosti razvoja gorskega kolesarstva v občini Bohinj. Acta geographica Slovenica 55-2. DOI: http://dx.doi.org/10.3986/AGS.1884

Polajnar, K. 2008: Ozaveščenost prebivalcev o varovanju mokrišč. Acta geographica Slovenica 48-1. DOI: http://dx.doi.org/10.3986/AGS48105

Poročilo o delu ZRC SAZU 1997 do 2015. Ljubljana.

Radinja, D., Šifrer, M., Lovrenčak, F., Kolbezen, M., Natek, M. 1976: Geografske značilnosti poplavnega področja ob Pšati. Geografski zbornik 15.

Radinja, D., Šifrer, M., Lovrenčak, F., Kolbezen, M., Natek, M. 1974: Geografsko proučevanje poplavnih področij v Sloveniji. Geografski vestnik 46.

Rančić, M., Blešić, I., Djordjević, J., Bole, D. 2016: Motivi obiskovalcev wellness centrov v Sloveniji. Acta geographica Slovenica 56-2. DOI: http://dx.doi.org/10.3986/AGS.723

Ravbar, M. 2004: Regionalni razvoj v pokrajinski členitvi Slovenije. Acta geographica Slovenica 44-1. DOI: http://dx.doi.org/10.3986/AGS44101

Ravbar, M. 2009: Ekonomsko geografsko vrednotenje naložb - razvojni dejavnik v regionalnem razvoju. Acta geographica Slovenica 49-1. DOI: http://dx.doi.org/10.3986/AGS49105

Ravbar, M. 2011: Ustvarjalne socialne skupine v Sloveniji: prispevek h geografskemu preučevanju človeških virov. Acta geographica Slovenica 51-2. DOI: http://dx.doi.org/10.3986/AGS51204

Ravbar, M., Bole, D., Nared, J. 2005: Ustvarjalno okolje in vloga geografije pri proučevanju konkurenčnosti mest: primer Ljubljane. Acta geographica Slovenica 45-2. DOI: http://dx.doi.org/10.3986/ AGS45201

Razpotnik Visković, N. 2011: Prostorska utesnjenost kmetij na obmestnih območjih. Acta geographica Slovenica 51-1. DOI: http://dx.doi.org/10.3986/AGS51105

Razpotnik Visković, N. 2015: Vrednotenje razvojnega potenciala obmestnih kmetij - metodologija. Acta geographica Slovenica 55-1. DOI: http://dx.doi.org/10.3986/AGS.704

Razpotnik Visković, N., Urbanc, M., Nared, J. 2013: Prostorska in razvojna vprašanja Alp. Georitem 12.

Ribeiro, D., Burnet, J. E., Torkar, G. 2013: Štiri okna obmejnega območja: dimenzije prostora opredeljene s podatki o spremembah pokrovnosti tal pridobljenih iz zgodovinskih zemljevidov. Acta geographica Slovenica 53-2. DOI: http://dx.doi.org/10.3986/AGS53204

Ribeiro, D., Somodi, I., Čarni, A. 2016: Prenosljivost napovednega modela razširjenosti vrste Robinia pseudacacia v severovzhodni Slovenji. Acta geographica Slovenica 56-1. DOI: http://dx.doi.org/ 10.3986/AGS.772

Rus, P., Razpotnik Visković, N., Nared, J. 2013: Upravljanje območij z vidika sprememb funkcijskih zaledij centralnih krajev: primer Gorenjske. Gorenjska v obdobju glokalizacije. Ljubljana.

Smrekar, A. 2004: Zmanjšano prenikanje padavinske vode v podtalnico na Ljubljanskem barju. Acta geographica Slovenica 44-2. DOI: http://dx.doi.org/10.3986/AGS44202

Smrekar, A. 2006: Z risanjem spoznavnih zemljevidov do poznavanja varstvenih pasov virov pitne vode. Acta geographica Slovenica 46-1. DOI: http://dx.doi.org/10.3986/AGS46101

Smrekar, A. 2011: Od deklarativne do dejanske okoljske ozaveščenosti na primeru Ljubljane. Acta geographica Slovenica 51-2. DOI: http://dx.doi.org/10.3986/AGS51203 
Smrekar, A., Polajnar Horvat, K., Erhartič, B. 2016: The beauty of landforms. Acta geographica Slovenica 56-2. DOI: http://dx.doi.org/10.3986/AGS.3039

Smrekar, A., Šmid Hribar, M., Erhartič, B. 2016: Stakeholder conflicts in the Tivoli, Rožnik Hill, and Šiška Hill Protected Landscape Area. Acta geographica Slovenica 56-2. DOI: http://dx.doi.org/ 10.3986/AGS.895

Smrekar, A., Šmid Hribar, M., Tiran, J., Erhartič, B. 2014: Interpretacija okolja na primeru Ljubljanskega barja. Georitem 24. Ljubljana.

Smrekar, A., Šmid Hribar, M., Tiran, J., Erhartič, B. 2016: A methodological basis for landscape interpretation: the case of the Ljubljana Marsh. Acta geographica Slovenica 56-2. DOI: http://dx.doi.org/ 10.3986/AGS.875

Smrekar, A., Tiran, J. (ur.) 2013: 2Bparks mainstream. Ljubljana.

Smrekar, A., Zorn, M., Komac, B. 2016: Heritage protection through a geomorphologist's eyes: from recording to awareness raising. Acta geographica Slovenica 56-1. DOI: http://dx.doi.org/10.3986/ AGS.3348

Šegina, E., Komac, B., Zorn, M. 2012: Vplivni dejavniki umikanja flišnih klifov na slovenki obali. Acta geographica Slovenica 52-2. DOI: http://dx.doi.org/10.3986/AGS52202

Šifrer, M. 1952: Obseg zadnje poledenitve na Pokljuki. Geografski vestnik 24.

Šifrer, M. 1955: Dolina Tolminke in Zalašce v pleistocenu. Geografski zbornik 3.

Šifrer, M. 1959: Nova geomorfološka dognanja v Koprskem Primorju. Geografski zbornik 5.

Šifrer, M. 1961a: Snežišča v Kamniških Alpah. Geografski zbornik 6.

Šifrer, M. 1961b: Porečje Kamniške Bistrice v pleistocenu. Dela SAZU 6, Ljubljana.

Šifrer, M. 1962: Geografski učinki neurja med Peco in zgornjo Pako. Geografski zbornik 7.

Šifrer, M. 1963: Nova geomorfološka dognanja na Triglavu, Triglavski ledenik v letih 1954-1962. Geografski zbornik 7.

Šifrer, M. 1967: Kvartarni razvoj doline Rašice in Dobrega polja. Geografski zbornik 10.

Šifrer, M. 1969: Kvartarni razvoj Dobrav na Gorenjskem. Geografski zbornik 11.

Šifrer, M. 1972: Nekatere smeri in pogledi geomorfološkega proučevanja na Slovenskem. Geografski vestnik 44.

Šifrer, M. 1974a: Kvartarni razvoj Dravinjskih goric in bližnjega obrobja. Geografski zbornik 14.

Šifrer, M. 1974b: Poglavitne značilnosti razvoja Škofjeloškega hribovja. Loški razgledi 21. Škofja Loka.

Šifrer, M. 1976: Geografski učinki žleda v gozdovih okrog Idrije in Postojne. Geografski zbornik 16.

Šifrer, M. 1977: Poplavna področja v porečju Dravinje. Geografski zbornik 17.

Šifrer, M. 1980: Katastrofalni učinki neurij v severovzhodni Sloveniji avgusta 1980. Geografski zbornik 20.

Šifrer, M. 1982: Kvartarni razvoj Škofjeloškega hribovja. Geografski zbornik 22.

Šifrer, M. 1983: Vzroki in učinki rečnih poplav na Slovenskem. Naravne nesreče v Sloveniji. Ljubljana.

Šifrer, M., Kunaver, J. 1978: Poglavitne značilnosti geomorfološkega razvoja Zgornjega Posočja. Zgornje Posočje, Zbornik 10. zborovanja slovenskih geografov. Ljubljana.

Šifrer, M., Lovrenčak, F., Natek, M. 1980: Geografske značilnosti poplavnih območij ob Krki pod Otočcem. Geografski zbornik 20.

Šifrer, M., Radinja, D., Meze, D. 1978: Osnovne smernice za proučevanje kvartarnih sedimentov in njihove izrabe na Slovenskem. Geografski vestnik 50.

Šifrer, M., Žagar, M. 1960: Geografski učinki neurja med Konjicami in Krškim. Geografski vestnik 32.

Šmid Hribar, M., Ferk, M. 2016: The role and importance of the landscape park Udin Boršt. Acta geographica Slovenica 56-1. DOI: http://dx.doi.org/10.3986/AGS.968

Šmid Hribar, M., Ledinek Lozej, Š. 2013: The role of identifying and managing cultural values in rural development. Acta geographica Slovenica 53-2. DOI: http://dx.doi.org/10.3986/AGS53402

Šmid Hribar, M., Lisec, A. 2011: Vloga inventarizacije in tipizacije pri učinkovitem varovanju drevesne dediščine v pokrajini: drevesna dediščina v Karavankah. Acta geographica Slovenica 51-1. DOI: http://dx.doi.org/10.3986/AGS51108 
Šprah, L., Novak, T., Fridl, J. 2014: Blaginja prebivalcev Slovenije po regijah: primerjava kazalnikov s poudarkom na zdravju. Acta geographica Slovenica 54-1. DOI: http://dx.doi.org/10.3986/AGS54104

Tiran, J. 2016: Merjenje kakovosti življenja v mestu: primer Ljubljane. Acta geographica Slovenica 56-1. DOI: http://dx.doi.org/10.3986/ags.828

Topole, M. 2009: Turistični potencial demografsko ogroženega območja Jurklošter. Acta geographica Slovenica 49-1. DOI: http://dx.doi.org/10.3986/AGS49104

Topole, M., Bole, D., Petek, F., Repolusk, P. 2006: Prostorske in funkcijske spremembe pozidanih zemljišč v izbranih podeželskih naseljih po letu 1991. Acta geographica Slovenica 46-2. DOI: http://dx.doi.org/10.3986/AGS46203

Tošić, R., Dragićević, S., Zorn, M., Lovrić, N. 2014: Landslide susceptibility zonation: a case study of the Municipality of Banja Luka (Bosnia and Herzegovina). Acta geographica Slovenica 54-1. DOI: http://dx.doi.org/10.3986/AGS54307

Urbanc, M. 2008: Zgodbe o resnični in zamišljeni pokrajini: primer slovenske Istre. Acta geographica Slovenica 48-2. DOI: http://dx.doi.org/10.3986/AGS48204

Urbanc, M., Breg, M. 2005: Prodna ravnina v mestnem prostoru: gramoznice kot prvina degradirane pokrajine. Acta geographica Slovenica 45-2. DOI: http://dx.doi.org/10.3986/AGS45202

Urbanc, M., Fridl, J. 2012: Education for active citizenship in spatial-planning processes: from teacher to student. Geografski vestnik 84-1.

Urbanc, M., Fridl, J., Kladnik, D., Perko, D. 2006: Atlant in slovenska nacionalna zavest v 2. polovici 19. stoletja. Acta geographica Slovenica 46-2. DOI: http://dx.doi.org/10.3986/AGS46204

Urbanc, M., Gašperič, P., Kozina, J. 2015: Geografsko zamišljanje pokrajin: analiza fotomonografije slovenske krajine. Acta geographica Slovenica 55-1. DOI: http://dx.doi.org/10.3986/AGS.836

Urbanc, M., Kladnik, D., Perko, D. 2014: Šest desetletij humane geografije in varstva okolja v Acti geographici Slovenici. Acta geographica Slovenica 54-2. DOI: http://dx.doi.org/10.3986/ AGS54201

Urbanc, M., Pipan, P. (ur.) 2011: Climalptour: podnebne spremembe in njihov vpliv na turizem v Alpah. Ljubljana.

Urbanc, M., Pipan, P. 2013: Prihodnost turizma v Alpah v luči prilagajanja podnebnim spremembam: nekatere ugotovitve iz projekta ClimAlpTour. Geografski vestnik 85-1.

Urbanc, M., Printsmann, A., Palang, H., Skowronek, E., Woloszyn, W., Konkoly Gyuró, E. 2004: Razumevanje hitro spreminjajočih se pokrajin v Srednji in Vzhodni Evropi v 20. stoletju. Acta geographica Slovenica 44-2. DOI: http://dx.doi.org/10.3986/AGS44204

Zorn, M. 2002: Podori v slovenskih Alpah. Geografski zbornik 42.

Zorn, M. 2008: Erozijski procesi v slovenski Istri. Geografija Slovenije 18. Ljubljana.

Zorn, M. 2009a: Erozijski procesi v slovenski Istri - 1. del: erozija prsti. Acta geographica Slovenica 49-1. DOI: http://dx.doi.org/10.3986/AGS49102

Zorn, M. 2009a: Erozijski procesi v slovenski Istri - 2. del: erozijska žarišča. Acta geographica Slovenica 49-2. DOI: http://dx.doi.org/10.3986/AGS49203

Zorn, M. 2016: Razstava ob sedemdesetletnici rednih opazovanj Triglavskega ledenika. Geografski vestnik 88-1.

Zorn, M., Gašperič, P. 2016: Geografska dediščina - sedem desetletij Zemljepisnega muzeja. Geografski vestnik 88-1. DOI: http://dx.doi.org/10.3986/GV88106

Zorn, M., Komac, B. 2004: Deterministično modeliranje ogroženosti zaradi zemeljskih plazov in skalnih podorov. Acta geographica Slovenica 44-2. DOI: http://dx.doi.org/10.3986/AGS44203

Zorn, M., Komac, B. 2007: Probabilistično modeliranje plazovitosti. Acta geographica Slovenica 47-2. DOI: http://dx.doi.org/10.3986/AGS47201

Zorn, M., Komac, B. 2008: Zemeljski plazovi v Sloveniji. Georitem 8. Ljubljana.

Zorn, M., Komac, B. 2010: Zgodovina znanstvene revije Acta geographica Slovenica. Acta geographica Slovenica 50-1. DOI: http://dx.doi.org/10.3986/AGS50101 
Drago Perko, Matija Zorn Sedemdeset let raziskovanj na Geografskem inštitutu Antona Melika ZRC ...

Zorn, M., Komac, B. 2011: Škoda zaradi naravnih nesreč v Sloveniji in svetu med letoma 1995 in 2010. Acta geographica Slovenica 51-1. DOI: http://dx.doi.org/10.3986/AGS51101

Zorn, M., Razpotnik Visković, N., Repolusk, P., Ferk, M. 2014: Prostorski in regionalni razvoj Sredozemlja - enotni pristop in izbrana orodja. Georitem 22. Ljubljana.

\section{Summary: Seventy years of research at the ZRC SAZU Anton Melik Geographical Institute}

(translated by the authors)

The Geographical Institute was founded in 1946 by the Slovenian Academy of Sciences and Arts. In 1976 it was named after Slovenia's greatest geographer, academy member Anton Melik (1890-1966), who served as the institute's first director. Since 1981, the institute has been one of the members of the Research Centre of the Slovenian Academy of Sciences and Arts (ZRC SAZU). In 2002 the Institute for Geography (established in 1962) and the Geographical Museum of Slovenia (established in 1946) were joined to the institute.

From the very beginning, the institute's main task has been to conduct basic and applied geographical research on Slovenia and its landscapes and to prepare basic geographical texts on Slovenia as a country and as a part of the world. Since Slovenia gained independence, in cooperation with other Slovenian geographers the institute's staff has prepared a large variety of basic geographical works on Slovenia as an independent country. These include national, world, school, and census atlases, a dictionary of geographical terminology, a lexicon of Slovenian place names, and a regional and general monograph. The institute participates in numerous projects in Slovenia and abroad, organizes academic conferences, trains junior researchers, and participates in professional exchanges. In the past ten years, the institute's research team has published over 3,000 bibliographic units and made over 500 presentations at conferences in Slovenia and abroad.

The institute has nine organizational units: the Department of Physical Geography, the Department of Human Geography, the Department of Regional Geography, the Department of Natural Disasters, the Department of Environmental Protection, the Department of Geographic Information Systems, the Department of Thematic Cartography, the Geographical Museum, and the Geographical Library. The institute also houses cartographic and geographical collections, and is the headquarters of the Commission for the Standardization of Geographical Names of the Government of the Republic of Slovenia.

Most of the Institute research work derives from the Institute's long-term research program Geografija Slovenije (Geography of Slovenia) and basic, applied, and target national projects, mainly funded by the Slovenia Research Agency, as well as international European projects, bilateral project, and other projects.

The institute issues six scholarly publications. Acta geographica Slovenica is a scientific journal published twice a year in English and Slovenian. The articles can be downloaded in Slovenian or English from the journal's homepage (http://ojs.zrc-sazu.si/ags). Geografija Slovenije (Geography of Slovenia) and Georitem (Georhythm) are series of volumes in Slovenian that appear several times a year. Volumes in the series GIS $v$ Sloveniji (GIS in Slovenia) are published in even years, volumes in the series Regionalni razvoj (Regional Development) in odd years, and volumes in the series Naravne nesreče (Natural hazards) every third year. The monographs are published in Slovenian with English summaries. 